\title{
Selection of axial growth sites in yeast requires Axl2p, a novel plasma membrane glycoprotein
}

\author{
Terry Roemer, Kevin Madden, James Chang, and Michael Snyder ${ }^{1}$ \\ Department of Biology, Yale University, New Haven, Connecticut 06520 USA
}

\begin{abstract}
Spa2p and Cdc10p both participate in bud site selection and cell morphogenesis in yeast, and spa2A cdc10-10 cells are inviable. To identify additional components important for these processes in yeast, a colony-sectoring assay was used to isolate high-copy suppressors of the spa2s cdc10-10 lethality. One such gene, $A X L 2$, has been characterized in detail. axl2 cells are defective in bud site selection in haploid cells and bud in a bipolar fashion. Genetic analysis indicates that $A X L 2$ falls into the same epistasis group as BUD3. Axl2p is predicted to be a type I transmembrane protein. Tunicamycin treatment experiments, biochemical fractionation and extraction experiments, and proteinase $K$ protection experiments collectively indicate that Axl2p is an integral membrane glycoprotein at the plasma membrane. Indirect immunofluorescence experiments using either Ax12p tagged with three copies of a hemagglutinin epitope or high-copy $A X L 2$ and anti-Ax12p antibodies reveal a unique localization pattern for Axl2p. The protein is present as a patch at the incipient bud site and in emerging buds, and at the bud periphery in small-budded cells. In cells containing medium-sized or large buds, Axl2p is located as a ring at the neck. Thus, Axl2p is a novel membrane protein critical for selecting proper growth sites in yeast. We suggest that Ax12p acts as an anchor in the plasma membrane that helps direct new growth components and/or polarity establishment components to the cortical axial budding site.
\end{abstract}

[Key Words: Bud site selection; cell morphogenesis; cell polarity; septins; plasma membrane glycoprotein]

Received January 10, 1996; revised version accepted February 20, 1996.

Polarized cell growth and asymmetric cell division are fundamental processes that are essential for the development of eukaryotes. Polarized cell growth forms many specialized structures that are critical for the function of individual cell types and coordinates diverse cellular interactions during development such as neuronal outgrowth to target cells, pollen tube growth during fertilization, and conjugation in fungi (Schnepf 1986). Asymmetric cell division, a separate but related event in which cells divide along specified cleavage planes, mediates appropriate cell-cell contacts, partitions cytoplasmic components, and helps establish asymmetric cellular structures (Rhyu and Knoblich 1995). This process is central to many aspects of eukaryotic and prokaryotic development, including spore development in Bacillus subtillus (Shapiro 1993), early embryogenesis in Caenorhabditis elegans (Hyman and White 1987; Cheng et al. 1994), mammalian neurogenesis (Chenn and McConnell 1995), and plant embryogenesis and development (Schnepf 1986).

Saccharomyces cerevisiae undergoes both polarized cell growth and asymmetric cell division and is an ideal

\footnotetext{
${ }^{1}$ Corresponding author.
}

model system to genetically dissect these processes (Drubin 1991; Chant 1994; Costigan and Snyder 1996). In yeast, the plane of cell division is determined by the site of bud formation, which is specified by the yeast cell type (Freifelder 1960; Hicks et al. 1977; Snyder 1989; Chant and Pringle 1995). Haploid $\mathbf{a}$ and $\alpha$ cells exhibit an axial budding pattern in which the bud forms directly adjacent to the previous site of budding, as marked by a bud scar on mother cells and a birth scar on daughter cells. Diploid a $/ \alpha$ cells exhibit a more complex bipolar budding pattern, in which daughter cells bud from the pole opposite their birth scar but mother cells are competent to bud from either pole. A "cytokinesis tag" model has been proposed to explain the axial budding pattern, whereby the previous bud site is tagged by cortical components that persist after cytokinesis; these components direct assembly of growth components at an adjacent site (Chant and Herskowitz 1991; Snyder et al. 1991; Madden et al. 1992; Flescher et al. 1993; Chant et al. 1995). Models to explain the bipolar budding pattern emphasize a hypothetical bipolar tag deposited to the bud tip early in the budding cycle and to the mother-bud neck region prior to cytokinesis (Chant and Herskowitz 1991; Snyder et al. 1991; Madden et al. 1992; Flescher et al. 1993; Chant and Pringle 1995). 
Selection of haploid axial sites is mediated by proteins associated with the neck filament complex. A series of 10-nm electron-dense filaments lie beneath the plasma membrane and surround the neck region in budding yeast (Byers and Goetsch 1976a,b; Byers 1981). These filaments are thought to be comprised of at least four proteins, the products of the $C D C 3, C D C 10, C D C 11$, and CDC12 genes (Haarer and Pringle 1987; Ford and Pringle 1991; Kim et al. 1991). These four proteins are homologous to one another and to proteins in other species and are collectively called septins (Nottenburg et al. 1990; DiDomenico et al. 1994; Neufeld and Rubin 1994; Sanders and Field 1994; Fares et al. 1995). The putative neck filament proteins and two associated proteins, Bud3p and Bud4p, each localize as a ring at the neck region; this ring persists after cytokinesis (Haarer and Pringle 1987; Ford and Pringle 1991; Kim et al. 1991; Chant et al. 1995; S. Sanders and I. Herskowitz, pers. comm. H.B. Kim, B.K. Haarer, and J.R. Pringle, pers. comm.). Each of these proteins is required for selection of axial growth sites in yeast (Flescher et al. 1993; Chant et al. 1995; S. Sanders and I. Herskowitz, pers. comm.). The septins, Bud3p, and Bud4p may form a tag that is recognized by other components of the bud site selection machinery. One additional component important for axial budding is Axllp (Fugita et al. 1994; Adames et al. 1995). This protein is expressed specifically in haploids and is critical for selecting the axial budding pattern.

Recognition of the axial tag and subsequent growth at this site is thought to be mediated by GTP-binding proteins. Rsrlp/Budlp, a RAS-related protein (Bender and Pringle 1989), and two proteins that regulate Rsrlp/ Budlp activity, Bud2p and Bud5p, constitute a GTPase cycle necessary for bud site recognition of both axial and bipolar sites in yeast (Chant and Herskowitz 1991; Chant et al. 1991; Park et al. 1993; Herskowitz et al. 1995). This GTPase cycle is hypothesized to recognize and recruit a second class of components (the polarity establishment components| that include Cdc24p, Cdc42p, Bemlp, and/or Spa2p to the growth site. Many of these proteins are highly polarized and localize as a patch at the incipient bud site and at the tips of budded cells /Snyder 1989; Ziman et al. 1993; K. Corrado and J.R. Pringle, pers. comm.). At least two of these proteins, Cdc24p and Spa2p, also participate in bud site selection, indicating that they are involved in early steps of the budding process (Sloat et al. 1981; Snyder 1989). The polarity establishment proteins are thought to somehow organize the actin cytoskeleton at the chosen site to direct cell-surface growth. The general relevance of this process is emphasized by the existence of highly conserved mammalian homologs to many different yeast polarity proteins (Shinjo et al. 1990; Ron et al. 1991; Chen et al. 1993; Ridley 1995).

Although a number of components important for the early steps of the budding process have been identified, membrane proteins important for this process have not been found. In other eukaryotes, type I membrane proteins, such as the integrins, help organize the cytoskeleton at growth sites (Clark and Brugge 1995). Because early growth events in yeast are also mediated at or near the plasma membrane, membrane proteins are expected to be involved in this process.

Described below is Axl2p, a novel yeast protein, that is essential for the axial budding pattern of haploid cells but is not required for the diploid budding pattern. The AXL2 (axial 2 bud site selection; see below) gene encodes a type I plasma membrane glycoprotein, exhibiting a unique immunolocalization pattern that overlaps with polarity establishment and neck filament-associated components and changes with the cell cycle. Axl2p is distinct from all known proteins participating in these processes because it contains both intracellular and extracellular domains. Axl2p may function analogously to integrins in higher eukaryotes, and our results suggest a novel mechanism for establishing sites of polarized growth in eukaryotes.

\section{Results}

AXL2 is a multicopy suppressor of spa2 $\Delta$ cdc10-10 lethality

SPA2 and CDC10 both participate in bud site selection and cell morphogenesis in yeast, and spa2s cdc10-10 cells are inviable (Flescher et al. 1993). To identify additional components important for these processes, a colony-sectoring assay (Costigan et al. 1994) was used to isolate $2 \mu$ multicopy suppressors of spa2d cdc10-10 lethality. The details of this screen will be presented elsewhere (K. Madden and M. Snyder, unpubl.). A total of 14 different genes rescued the lethality of spa2s cdc10-10 cells when present in high copy. One particularly strong suppressor plasmid possessed a $4.7-\mathrm{kb}$ insert that maps to the right arm of chromosome IX. This plasmid is predicted to encode a previously uncharacterized 823 codon open reading frame (ORF) (YIL140W; accession no. Z38059) designated $A X L 2$, as well as the complete REV7 gene and the carboxy-terminal 69 residues of the 527 amino acid TCP1 gene. No other ORFs $>150$ amino acids in length were detected. To determine the ORF responsible for suppressing inviability of the spa2s cdc1010 strain, each gene was cloned and retested separately (see Materials and methods). Only the AXL2 ORF suppressed spa2 $\Delta$ cdc10-10 inviability. The original $A X L 2$ plasmid isolated did not suppress defects associated with loss of either SPA2 or CDC10 single mutations; neither the shmoo defect of spa2 cells (Gehrung and Snyder 1990) nor the temperature-sensitive growth defect of cdc10-10, cdc3-1, cdc11-1, or cdc12-1 mutants (Hartwell et al. 1973) were alleviated by multicopy $A X L 2$ (data not shown). Thus, high-copy $A X L 2$ either suppresses only the synthetic phenotype of spa2A cdc10-10 cells or AXL2 suppression is not detectable in the different assays used for analyzing individual mutant strains. Cells deleted for AXL2 possess an axial-specific
budding pattern defect

To help determine the role of $A X L 2$ in yeast, a complete deletion of one genomic copy of the gene was created in 
a diploid strain using the PCR disruption technique of Baudin et al. (Rothstein 1983; Baudin et al. 1993; see Materials and methods). Three independent axl2. $\triangle 1: \because H I S 3 / A X L 2$ heterozygotes were sporulated, and $>20$ tetrads were dissected for each strain. In each case, histidine prototrophy segregated $2 \mathrm{His}^{+}: 2 \mathrm{His}^{-}$, and the $\mathrm{His}^{+}$and $\mathrm{His}^{-}$segregants formed equal-sized colonies at $18^{\circ} \mathrm{C}, 30^{\circ} \mathrm{C}$, and $37^{\circ} \mathrm{C}$. Therefore, $A X L 2$ is not essential for yeast cell growth.

Despite the similar growth rate between $A X L 2$ and axl2-41::HIS3 strains, axl2 null strains possessed a slightly rough colony surface that was not evident in the isogenic wild-type colony morphology. To explore this phenotype further, the budding pattern of axl2 cells was examined. Spore progeny from three complete axl2$\Delta 1:: H I S 3 / A X L 2$ tetrads were grown in liquid medium to early log phase, formaldehyde-fixed, and stained with Calcofluor white to visualize the chitin-rich bud scars that mark previous sites of budding (Hayashibe and Katohda 1973). Wild-type (His ${ }^{-}$/ haploid cells contain bud scars clustered at one end of the cell or as a trail across the surface (Fig. 1), consistent with the observation that new buds form adjacent to previous sites (Freifelder 1960; Hicks et al. 1977; Madden and Snyder 1992; Flescher et al. 1993; Chant and Pringle 1995|. In contrast, haploid axl2 $\Delta$ strains exhibit a bipolar budding pattern in which bud scars are located at both ends of the cell (Fig. 1).

The budding pattern defect was analyzed quantitatively in two cell types: new mothers and daughters (Flescher et al. 1993). Calcofluor-stained cells with a visible bud and single bud scar (new mothers; see bottom cell in axl2 panel of Fig. 1) or unbudded cells with two bud scars were classified according to the scheme outlined in Table 1. Class I cells form buds adjacent to the bud scar, class III cells bud at the pole opposite from the bud scar, and class II cells form buds in the central region. Wildtype new mother cells bud adjacent to the bud scar exclusively $(n=232)$ (Table $1 \mathrm{~A})$, in agreement with previous results (Snyder 1989; Madden et al. 1992; Flescher et al. 1993; Chant and Pringle 1995). In contrast, $>45 \%$ of axl2 null cells $(n=284)$ budded at the pole distal to the bud scar.

The axl2 axial budding pattern defect was also analyzed in daughter cells forming their first bud (Table 1B, daughters|. Calcofluor-stained cells, which possess either a diffusely staining birth scar and a single bud or a birth scar and one bud scar, were scored according to the scheme described above. Over $99 \%$ of wild-type daughter cells $(n=112)$ form their first bud adjacent to the birth scar, in agreement with previous results (Chant and Pringle 1995). Remarkably, the budding pattern of $a x 12$ daughter cells is completely reversed; the first bud forms exclusively at the distal pole $(n=200)$.

Budding patterns were also analyzed in diploid strains. As shown in Table 2, MATa/MATa ax12::HIS3/axl2::HIS3 diploid cells bud in a bipolar fashion, indistinguishable from that of wild-type cells $>200$ cells were scored for each strain). Thus, AXL2 is required only for proper bud site selection in haploid cells.
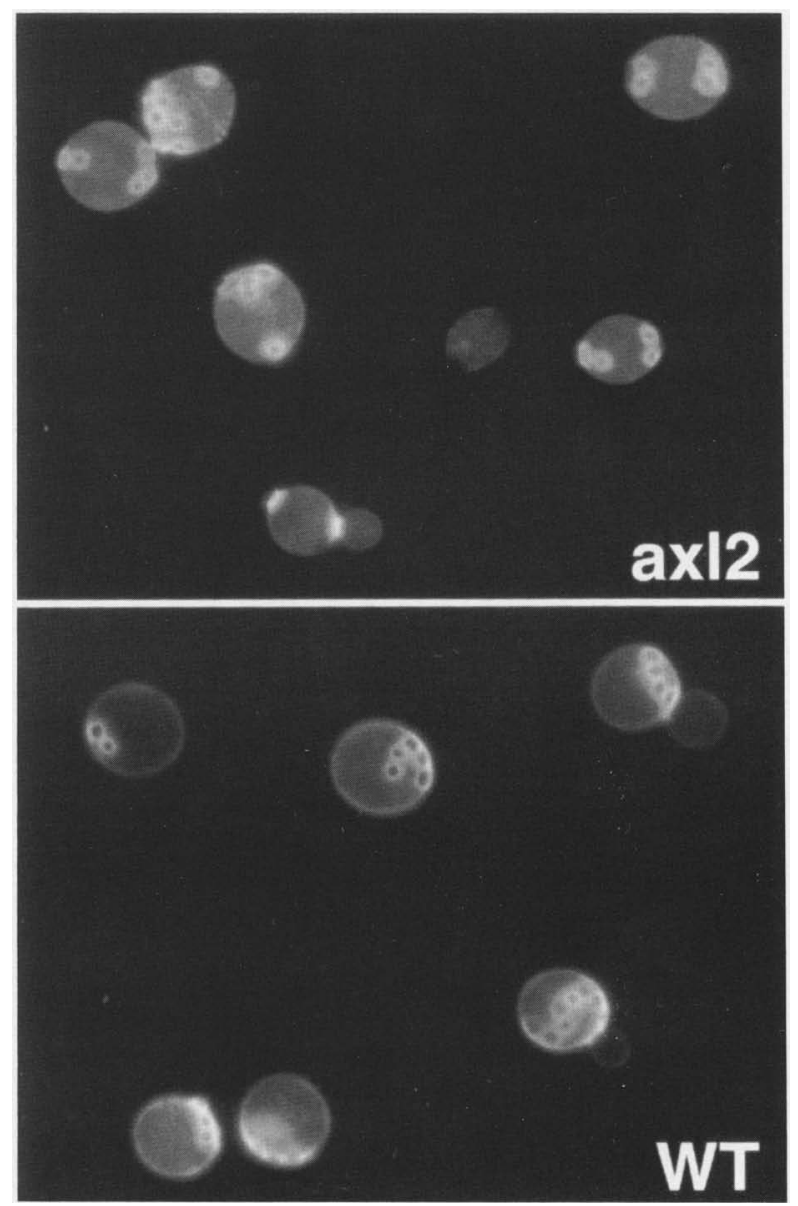

Figure 1. Budding patterns in axl2s and wild-type cells. axl241::HIS3 cells (Y1153) and wild-type cells (Y1155) were stained with Calcofluor. In wild-type cells, bud scars form a cluster or trail across the cell surface. In contrast axl2s cells undergo bipolar budding and have scars at both ends of the cell.

The axl2 haploid-specific budding defect is very similar to those reported for bud3 and bud4 cells /Chant and Herskowitz 1991; Chant et al. 1995). To explore the epistatic relationship between AXL2 and BUD3, ax12A, bud3 $\Delta$, and ax12 $\Delta$ bud3 $\Delta$ double mutant strains were constructed in an isogenic background and analyzed (see Materials and methods). axl2 $\Delta$ cells have a similar, albeit slightly more severe defect in bud site selection than bud $3 \Delta$ cells (Table 1B, haploid daughters). ax12 $\Delta$ bud3 $\Delta$ strains bud in a bipolar fashion identical to strains containing axl2 $\Delta$ alone (Table 1). The relationship between AXL2 and RSR1/BUD1, a gene needed for budding at both axial and distal sites, was also analyzed. ax12 $\Delta$ rsr $1 \Delta /$ bud $1 \Delta$ cells bud close to randomly, similarly to rsr $1 \Delta /$ bud1 1 cells (Table 1 ). These results indicate that $A X L 2$ is in the same epistasis group as BUD 3 but in a different group from RSR1/BUD1.

\section{AXL2 null cells possess a variety of morphological defects}

Although the most severe defect of axl2 cells is in their 
Table 1. Budding patterns of haploid cells

\begin{tabular}{lcccc}
\hline & \multicolumn{4}{c}{ Class } \\
\cline { 2 - 5 } Strain & A. Haploid new mothers & \\
\hline \multicolumn{5}{c}{} \\
Wild type & 100 & 0 & 0 & 232 \\
axl2 & 51.8 & 3.2 & 45.1 & 284 \\
bud3 & 46.3 & 10.6 & 43.1 & 216 \\
axl2 bud3 & 43.1 & 6.0 & 50.9 & 216 \\
bud1 & 15.5 & 65.3 & 19.2 & 239 \\
axl2 bud1 & 15.9 & 68.2 & 15.9 & 227 \\
& $B .4$ Haploid daughters & & \\
Wild type & 99.1 & 0 & 0.9 & 112 \\
axl2 & 0 & 0 & 100 & 200 \\
bud3 & 23.1 & 2.2 & 74.7 & 178 \\
axl2 bud3 & 0.7 & 1.4 & 97.9 & 146 \\
bud1 & 5.1 & 54.9 & 40.1 & 237 \\
axl2 bud1 & 2.2 & 58.2 & 39.6 & 227 \\
\hline
\end{tabular}

(A) Budding patterns of haploid cells, containing either a single bud and a single bud scar or two bud scars, were scored as described in the text (Madden and Snyder 1992; Flescher et al. 1993). Percentages are indicated. (B) Budding patterns of daughter cells budding for the first time. Cells, containing either a bud and a single birth scar or a bud scar and a birth scar, were scored as described. Strains scored are wild type (Y1155), axI2

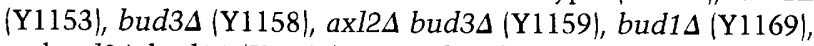
and axl2 $\Delta$ bud1 $(\mathrm{Y} 1168)$. Note that bud1 $\Delta$ daughter cells do not bud randomly by this analysis but exhibit a preference for the distal site.

budding patterns, loss of $A X L 2$ results in several morphological defects of lower penetrance. axl2 null strains often form short chains of cells connected at their ends (Fig. 2). Although most chains are very short, some chains contain as many as $8-10$ cells. As shown in Table 3 , the axl24 cytokinesis defect was quantitated by counting the number of buds and cell bodies per chain (Flescher et al. 1993). The ratio of cell bodies plus buds per chain for axl2 cells is $2.65-3.18$ as compared to 1.65 for wild-type cells. Interestingly, bud 3 null strains in the same background also show a mild cytokinesis defect (cell bodies plus buds per chain $=1.82-2.11$ ), consistent with its participation in processes other than bud site selection (Chant et al. 1995). The bud3 defect appears to be additive with the axl2 defect (cell bodies plus buds per chain of axl2 bud3 cells $=3.25-3.55$ ), suggesting that $B U D 3$ and $A X L 2$ contribute to cytokinesis in different ways.

The linear chains of cells observed in axl2 null strains probably result from a defect in cell wall separation as judged by two criteria. First, staining cells with Hoechst 33258 , a DNA-binding dye, reveals that each of the large cells contain a single nucleus. Second, a mild spheroplasting treatment largely disconnects the cells (Table 3).

Additional morphological phenotypes associated with the loss of $A X L 2$ include the occasional occurrence of elongated necks and protruding bud scars (Fig. 2). This latter feature is particularly evident upon Calcofluor staining (data not shown). In addition, $\sim 24 \%$ of buds in both haploid and diploid cells appear to "droop" (i.e., the bud is significantly longer on one side than the other; two examples are shown in Fig. 2) $(n=334)$. Droopy buds are not observed in wild-type cells $(n>300)$. These observations suggest that initial bud formation and/or neck formation events are altered in axl2 cells. Consistent with these possibilities, chitin staining in ax12 null cells usually appears more diffuse around the neck region than that observed in wild-type cells (data not shown).

Many polarity components in yeast participate in mating as well as vegetative growth (Field and Schekman 1980; Gehrung and Snyder 1990; Chenevert et al. 1992; Costigan et al. 1992; Read et al. 1992). Therefore, the role of Axl2p in mating was also analyzed. During mating, wild-type yeast arrest in $G_{1}$ in response to mating pheromone and form projections toward their mating partner. The two cells then fuse at their projection tips. axl2 null strains exposed to $5 \mu \mathrm{g} / \mathrm{ml}$ of $\alpha$-factor form projections similar to wild type. However, the site of projection formation is altered. Wild-type cells exposed to high isotropic concentrations of pheromone usually form their projections adjacent to the previous bud scar (Madden and Snyder 1992). In contrast, axl2 cells form projections at the pole distal from their previous bud scar (data not shown). Thus, axl2 cells form normal projections but at an aberrant site in high concentrations of pheromone. A possible mating defect of axl2 cells was also investigated. Quantitative matings of axl2 cells with either wild-type cells (unilateral matings) or with axl2 cells (bilateral matings) did not reveal a difference in mating efficiency compared with matings between wildtype cells (data not shown). In summary, these results suggest a role for Axl2p in polarized cell growth during budding; no analogous role has been found for Axl2p during mating.

\section{The Axl2p predicted sequence}

The DNA sequence of the $A X L 2$ gene was determined (see Materials and methods). $A X L 2$ is predicted to encode

Table 2. Budding patterns of diploid cells

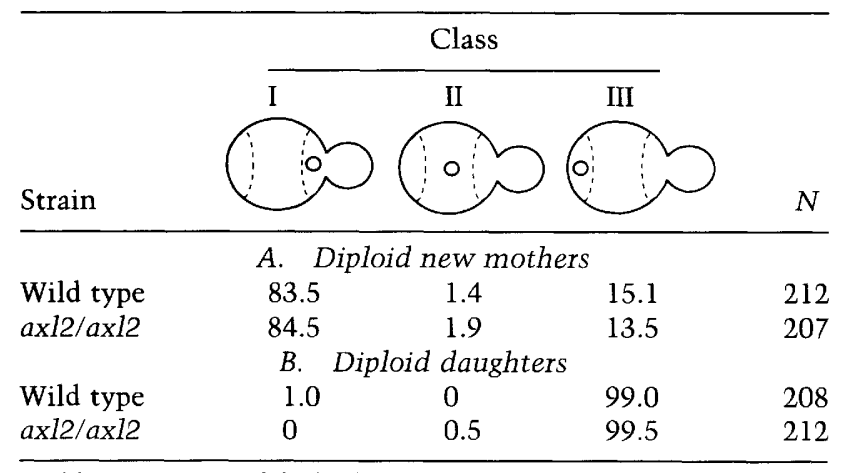

Budding patterns of diploids as described in Table 1. The strains scored are Wild type (Y270), ax124/ax124 (Y1157). 


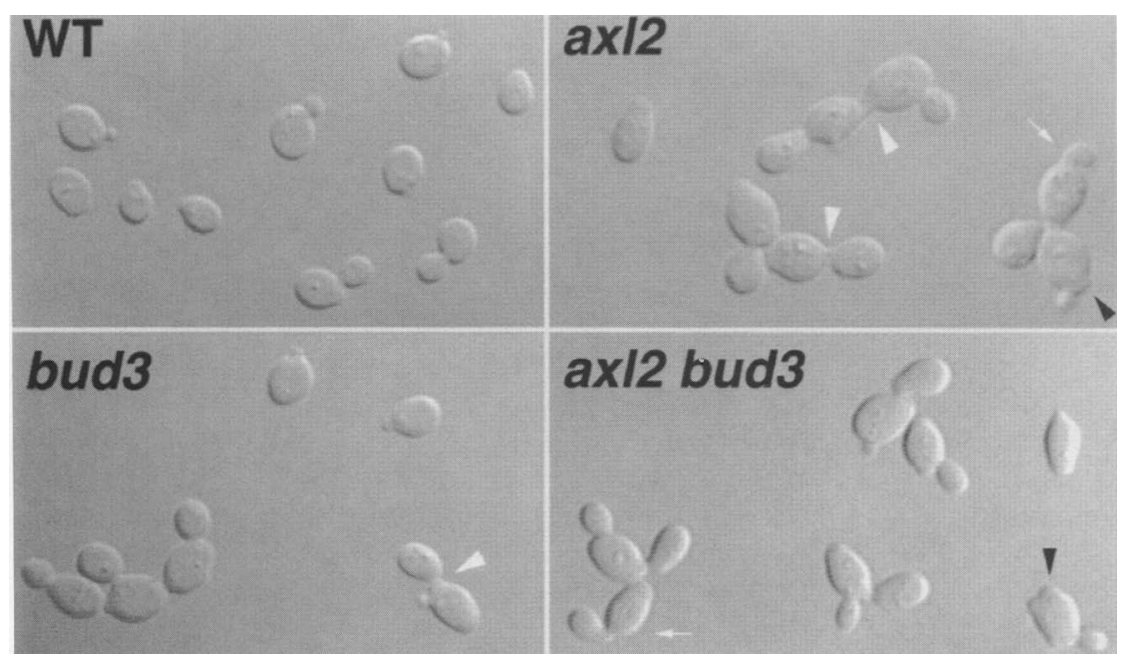

Figure 2. Morphology of wild-type (Y1155), ax124 (Y1153), bud3 $(\mathrm{Y} 1158)$, and bud3 $\Delta$ axl2 $\Delta$ cells (Y1159) as viewed by differential-interference contrast microscopy. ax $2 \Delta$, bud $3 \Delta$, and bud $3 \Delta$ ax $12 \Delta$ cells often form chains. Some rare longer chains are shown. In addition, the ax12 and bud3s axl2 $\Delta$ cells often have droopy buds (white arrows), elongated necks (white arrowheads), and prominent bulges (black arrowheads), which based on Calcofluor staining appear to be bud scars. The right-most chain of cells in the axl2 $\Delta$ panel is from a scparate field and was included here. an 823-amino-acid protein possessing two hydrophobic regions. The first region is 22 amino acids in length and is expected to form an amino-terminal signal sequence; the second is 26 residues long and is predicted to form a transmembrane domain 294 amino acids from the carboxyl terminus (Fig 3A,B). Proteins with these features are predicted to possess a type I membrane topology. For Axl2p, the amino-terminal two-thirds of the protein would be exposed extracellularly, whereas the carboxyterminal third of the protein would remain cytoplasmic. Consistent with this predicted topology, the amino-terminal domain of Axl2p is S/T-rich, a characteristic shared by many cell surface proteins both in $S$. cerevisiae and other eukaryotes (Cid et al. 1995). The predicted extracellular domain of $\mathrm{Axl} 2 \mathrm{p}$ contains 16 potential sites for $N$-linked glycosylation. In addition to the highly hydrophilic nature of the carboxy-terminal third of the protein, interesting features of $\mathrm{Axl} 2 \mathrm{p}$ include two tandem copies of a potential SH3 domain-binding motif (P-X-X-

Table 3. Cytokinesis defects in ax12 $\Delta$ and bud $3 \Delta$ cells

\begin{tabular}{lll}
\hline $\begin{array}{l}\text { Relevant } \\
\text { genotype } \\
\text { (strain) }\end{array}$ & $\begin{array}{l}\text { Cell bodies } \\
\text { and buds/ } \\
\text { unit-whole } \\
\text { cell }(N)\end{array}$ & $\begin{array}{l}\text { Cell bodies } \\
\text { and buds/ } \\
\text { unit-spheroplasts } \\
(N)\end{array}$ \\
\hline AXL2 BUD 3 & $1.65(702)$ & $1.59(411)$ \\
axl2 B BUD3 & $\begin{array}{l}1.65(745) \\
2.65(427)\end{array}$ & $1.62(402)$ \\
AXL2 bud3A & $3.18(412)$ & $1.52(405)$ \\
ax12 bud3A & $2.82(894)$ & $1.67(457)$ \\
\hline
\end{tabular}

Whole cells and spheroplasts werc quantitated as the ratio of the number of buds plus cells per chain. Individual numbers indicate the results of different experiments. The strains analyzed

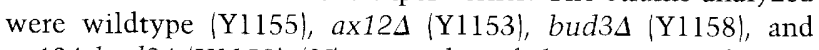
ax12 $\Delta$ bud3s (Y1159). $(N)=$ number of chain examined.
P) (Cohen et al. 1995) spanning amino acids 635-643, as well as a candidate MAP kinase consensus site (P-X-S) $\mathrm{T}$-P) within the second putative $\mathrm{SH} 3$-binding site (Alvarez et al. 1991), and a Cdc28 kinase consensus site (S/TP-X-basic) (Moreno and Nurse 1990) at amino acids 725728. Axl2p is a novel protein, as data base searches have failed to identify any overall similarity to known proteins.

\section{A AxI2p Predicted Features}

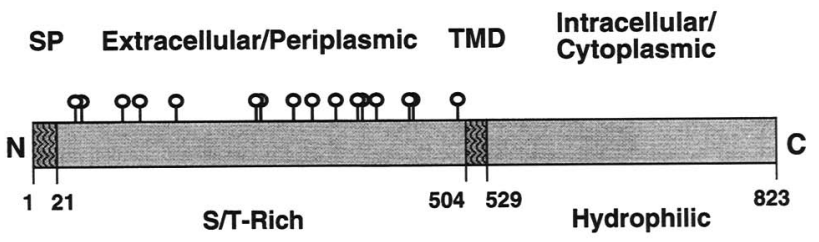

\section{B Ax12p Predicted Sequence}

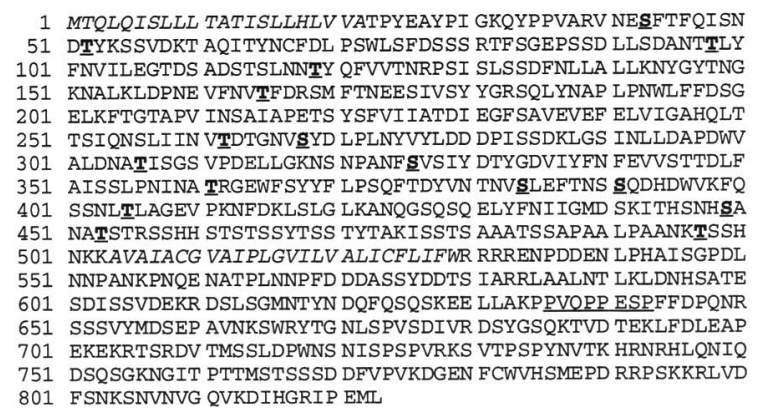

Figure 3. $(A)$ The predicted structure of Ax12p. Numbers indicate amino acid residues. (SP) Signal peptide; (TMD) Transmembrane domain. Circles indicate potential sites of protein glycosylation. $(B)$ The predicted sequence of Axl2p. The putative signal sequence and transmembrane segments are indicated by italics, potential sites of $N$-linked glycosylation are bold and underlined, and two tandem possible SH3-binding motifs are underlined. 
DNA sequence analysis also predicts the presence of three MluI cell cycle box (MCB)-related sequences in the promoter of $A X L 2$. MCB elements, possessing the consensus sequence ACGCGTNA are commonly found in the promoter region of many classes of genes that are preferentially expressed at the $G_{1} / S$ transition, including SWI4 and DNA replication factor genes (Johnston et al. 1991). In cases where it has been studied, these elements are required for $\mathrm{G}_{1} / \mathrm{S}$-specific expression (Johnston and Lowndes 1992). AXL2 has one perfect MCB element starting at position -365 and two imperfect MCB elements, ACGCGaNA and tCGCGTNA, that flank it; these latter elements begin at positions -384 and -331 , respectively. Thus, we expect that $A X L 2$ is expressed highest at the $G_{1} / S$ transition. This prediction is consistent with the immunolocalization results presented below in which Axl2p is detected most readily in cells with nascent buds.

\section{Axl2p is a 200- to 220-kD protein equally abundant in MATa, MAT $\alpha$, and MATa/MAT $\alpha$ cell types}

To begin characterization of the AXL2 gene product, polyclonal antibodies were raised against a glutathione $S$-transferase (GST)-Axl2p fusion protein (see Materials and methods). In addition, the $A X L 2$ gene was tagged at its genomic locus with three copies of the hemagglutinin (HA) epitope coding sequence (see Materials and methods); the resulting $A X L 2: \because 3 X H A$ allele complemented the axl2 $\Delta$ budding pattern and other defects (data not shown). Immunoblot analysis with affinity-purified antiAxl2p antibodies specifically detects a $200-$ to $220-\mathrm{kD}$ species in the total cell lysate of an Axl2p-overexpressing strain (Fig. 4A). Identical results were obtained using anti-Axl2p antibodies to probe lysates from cells containing genomic levels of Axl2p expression, although the signal was much lower (data not shown). No detectable Axl2p was present in axl2-deleted strains (Fig. 4A). AXL2:: $3 X H A$ strains express a similar-sized protein specifically detected by the anti-HA monoclonal antibody (shown below in Fig. 8). This protein is not detected in untagged strains.

The $A X L 1$ gene is also important for haploid bud site selection, and $A X L 1 \mathrm{mRNA}$ is expressed in both haploid $a$ and $\alpha$ cells, but not in a/ $\alpha$ diploid strains (Fugita et al. 1994). Therefore, to determine whether Axl2p is specifically expressed in haploid cells, Axl2p::HA levels were examined in haploid and diploid cells using immunoblot analysis. Proteins were prepared from haploid $a, \alpha$, and diploid $\mathbf{a} / \alpha$ cells and probed with the anti-HA monoclonal antibody. Equal levels of Axl2p::HA were detected in all three cell types (data not shown). Thus, like BUD3 (Chant et al. 1995), AXL2 is expressed at equal levels in both haploid and diploid cells, even though AXL2 does not participate in bud site selection in diploids.

\section{Axl2p is an N-linked glycosylated integral membrane protein}

In the absence of protein modification, Axl2p is pre-

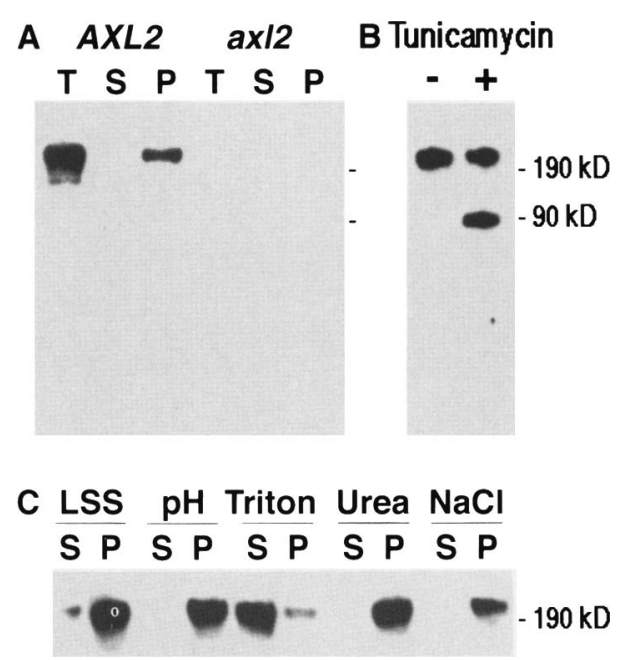

Figure 4. Biochemical analysis of Axl2p. (A) Proteins from total yeast cell lysates $(T)$, cytosol $(100,000 \mathrm{~g}$ supernatants $)(\mathrm{S})$, and membrane fractions $(100,000 \mathrm{~g}$ pellets $)(\mathrm{P})$ were separated in $10 \%$ polyacrylamide gels containing SDS and immunoblot probed with anti-Axl2p antibodies. This experiment shows the

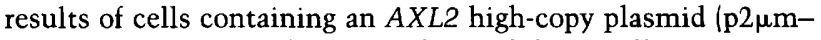
$A X L 2$ ); identical results were obtained from cells containing genomic levels of Axl2p except the signal was weaker. $(B)$ Proteins prepared from yeast strains treated with tunicamycin and control untreated cells were separated and transferred to Immobilon, and immunoblots were probed as in $A .|C|$ Yeast cell lysates were either pelleted directly at $10,000 \mathrm{~g}$ (LSS), or treated with $0.1 \mathrm{M} \mathrm{Na}_{2} \mathrm{CO}_{3}(\mathrm{pH}), 1.0 \%$ Triton X-100 (Triton), $1.6 \mathrm{M}$ urea or $0.6 \mathrm{M} \mathrm{NaCl}$ and centrifuged at $100,000 \mathrm{~g}$ for $20 \mathrm{~min}$. Proteins from the supernatants $\langle\mathrm{S}\rangle$ and pellets $(\mathrm{P}\rangle$ were separated and probed as above.

dicted by its putative amino acid sequence to migrate as a $90-\mathrm{kD}$ polypeptide. However, Axl2p migrates substantially slower than expected when detected with either affinity-purified Axl2p antibodies or the anti-HA antibody. To examine the nature of this difference in mobility, cells maintaining the multicopy plasmid, $\mathrm{p} 2 \mu \mathrm{m}-$ $A X L 2$, were incubated briefly $(30 \mathrm{~min})$ in the presence of tunicamycin, a potent inhibitor of $N$-linked glycosylation (Orlean et al. 1991), and the mobility of Axl2p was examined. A new Axl2p species of $90 \mathrm{kD}$ is evident after treatment with tunicamycin (Fig. 4B), close to that predicted from the DNA sequence. This result suggests that Axl2p is modified heavily by $N$-linked glycosylation and that this glycosylation is the primary source of its aberrant mobility.

Because Axl2p is predicted to contain a signal sequence and a transmembrane segment domain, the possibility that it is an integral membrane protein was explored by standard fractionation and extraction experiments (Goud et al. 1988; Walworth et al. 1989; Ljungdahl et al. 1992; Roemer et al. 1994). Yeast cell lysates were prepared and centrifuged at $100,000 \mathrm{~g}$, which pellets most cellular membranes. Supernatant and pellet fractions were probed with anti-Axl2p antibodies. As shown in Figure 4A, Axl2p pellets with the total mem- 
brane fraction. To determine which class of membrane contains Axl2p, cell lysates were prepared and centrifuged at $10,000 \mathrm{~g}$, which preferentially pellets plasma membranes (Goud et al. 1988). Most Axl2p is sedimented in the plasma membrane fraction (Fig. 4C), consistent with the protease protection results and the immunofluorescence data present below.

To determine whether Ax12p is an integral or peripherally associated membrane protein, extraction experiments were performed (Goud et al. 1988; Ljungdahl et al. 1992; Roemer et al. 1994). Yeast cell lysates were treated with one of the following: $0.6 \mathrm{M} \mathrm{NaCl}$ or $1.6 \mathrm{~m}$ urea, which removes peripherally associated membrane proteins; $0.1 \mathrm{M} \mathrm{Na}_{2} \mathrm{CO}_{3}$ (pH 11.0), which releases the internal soluble material from lysed membrane vesicles (Fujiki et al. 1982/ and peripheral membrane proteins; or Triton X-100, which solubilizes integral membrane proteins. The lysates were then spun at $100,000 \mathrm{~g}$, and supernatant and pellet fractions probed with anti-Axl2p antibodies. As shown in Figure 4C, Axl2p is not solubilized with either high $\mathrm{NaCl}$, urea, or $\mathrm{Na}_{2} \mathrm{CO}_{3}$ but is solubilized with Triton X-100. In contrast, control immunoblot experiments using the same sample preparations and an anti-actin antibody revealed that the actin normally pelleted after extraction with buffer preferentially solubilizes with $\mathrm{NaCl}$, urea, and $\mathrm{Na}_{2} \mathrm{CO}_{3}$ treatments, but not with Triton X-100 (data not shown). Thus, these data indicate that Axl2p is an integral membrane protein.

\section{Ax12p is a type I plasma membrane protein}

To determine whether Axl2p is a plasma membrane type I integral membrane protein with a cytoplasmic carboxyterminal domain and an extracellular amino-terminal domain, proteinase $\mathrm{K}$ protection experiments were performed according to Trueheart and Fink (1989; Fig. 5).

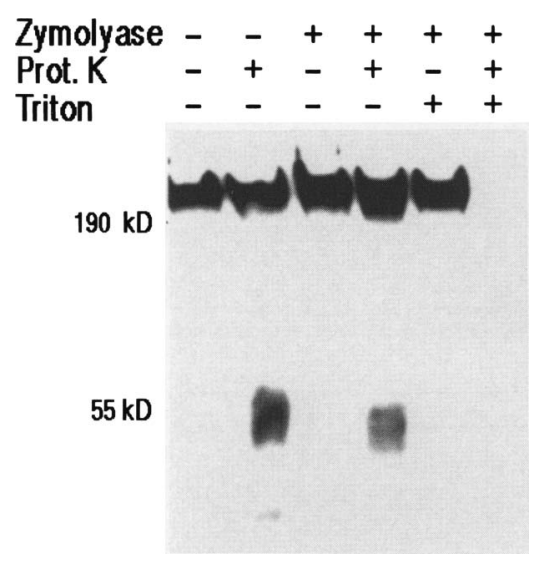

Figure 5. Proteinase $\mathrm{K}$ protection experiments. Yeast cells were incubated in the presence $(+)$ or absence $(-)$ of Zymolyase $\mathrm{T} 100,000$, proteinase $\mathrm{K}$, and/or Triton X-100. Proteins were then separated by gel electrophoresis, and immunoblots probed with the Axl2p polyclonal antibody raised against the predicted intracellular cytoplasmic domain.

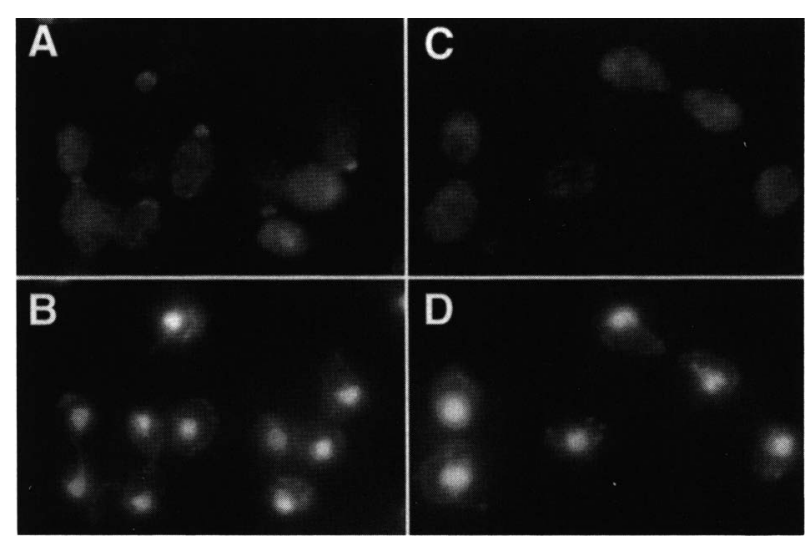

Figure 6. Diploid cells containing either two copies of $A X L 2:$ : $3 X H A(Y 1165 ; A)$ or Axl2p without an epitope tag (Y270; C) were stained with $12 \mathrm{CA} 5$, an anti-HA antibody by indirect immunofluorescence. $(B, D)$ Hoechst 33258 DNA staining of the cells in $A$ and $C$, respectively.

Yeast whole cells and intact spheroplasts were treated with proteinase $\mathrm{K}$, and the resulting proteins were probed with antibodies raised specifically to the carboxyterminal 294 amino acids of Axl2p. As shown in Figure 5 (lanes 1-4), a broad collection of 50- to $55-\mathrm{kD}$ proteolytic fragments were detected. Presumably, these fragments contain the cytoplasmic domain of Axl2p, which is protected from protease treatment. Consistent with this interpretation, addition of detergent solubilizes the plasma membrane and exposes this portion of the protein to complete proteolysis (Fig. 5, lanes 5,6). A modest discrepancy between the apparent size of these proteolytic fragments and the predicted molecular mass of the carboxyterminal domain plus the preceding hydrophobic stretch $(38 \mathrm{kD})$ may be attributable to the hydrophilic nature of the Axl2p carboxyl terminus, post-translational modification, and/or the incomplete extracellular digestion by the protease. Consistent with the latter possibility is the presence of mature protein and multiple proteolytic fragments in these experiments. In summary, these experiments indicate that Axl2p is a type I plasma membrane protein.

\section{Axl2p localizes to emerging buds and the neck}

To determine the subcellular localization of Axl2p, indirect immunofluorescence was performed using either Axl2p::HA cells and anti-HA antibodies or Axl2p cells and anti-Axl2p antibodies. As shown in Figure 6, staining of diploid cells that have homozygous copies of AXL2::3XHA reveals a novel localization pattern. Ax12p is localized to discrete sites at the cell periphery, and these sites vary with the cell cycle. Both haploid and diploid cell types exhibit similar localization patterns (>1000 cells were analyzed for each cell type). Peripheral staining is not detected in the isogenic, untagged parental strain (Fig. 6C).

Axl2p::HA staining is most intense in cells with 
emerging buds; the nascent bud stains strongly as a crescent-shaped patch at the edge of the cell (Fig. 7D,E). In small-budded cells /cells with buds $\leqslant 1 / 3$ the size of the mother cell), staining is throughout the periphery of the bud (Fig. 7F), consistent with the cell fractionation and protease protection experiments. As the bud continues to grow, Axl2p::HA staining at the bud periphery diminishes and staining is observed as a ring at the mother-bud neck $(>80 \%$ of cells counted $(n=201))$; ring staining is less intense than the nascent bud staining (Fig. 7G,H). This ring lies perpendicular to the mother/daughter axis and usually resides just inside the bud (Figs. 6A, top cell, and $7 \mathrm{H}$ ). As the cells enter mitosis (as judged by DNA staining with Hoechst 33258), a second ring at the neck usually becomes visible (Fig. 7I). One ring lies just inside the bud as before, whereas the second ring, which is often much fainter, lies just inside the mother cell (Fig. $7 \mathrm{I}, \mathrm{J}$, left cell). In many cells late in mitosis, and in all cells with separated nuclei undergoing cytokinesis, two cellrings of equal intensity are observed (Fig. 7J, right cell, and $\mathrm{K})$.

Several Axl2p staining patterns are observed in unbudded cells. The majority $161 \%$ of unbudded cells; number of unbudded cells counted $=219 \mid$ contain an intact ring (Fig. 7A,K, bottom left cell) or sometimes a partial one. We suggest that these rings remain from the former neck region after cytokinesis. At a much lower frequency $(3.2 \%)$ cells with a small patch are observed; these patches are interpreted as material appearing at the incipient bud site. In addition, occasionally $(0.5 \%)$ cells are found that have both a small patch and a ring or partial ring (Fig. $7 \mathrm{~B}, \mathrm{C}$ ); in diploid cells, the patch and ring lie on opposite sides of the cell. We suggest that these cells contain both an Axl2p ring remaining after cytokinesis and a new Axl2p patch appearing at the incipient bud site.

Attempts were also made to localize $\mathrm{Axl} 2 \mathrm{p}$ using Axl2p polyclonal antibodies. Significant signals above background were not observed in wild-type cells containing genomic copies of $A X L 2$. However, in strains containing $A X L 2$ on a high-copy plasmid, Axl2p localization was similar to that of $\mathrm{Axl} 2 \mathrm{p}: \mathrm{HA}$, except that neck staining was less prominent (data not shown). Interestingly, however, many cells containing high-copy AXL2 have elongated buds $(\sim 30 \%$ of budded cells); these cells stain at the bud tip and to a lesser extent along the sides of the bud.

In summary, Axl2p localizes to sites where bud emergence is occurring or about to occur. In addition, Axl2p is localized as a ring at the neck in budded cells. The staining of $\mathrm{Axl} 2 \mathrm{p}$ is reminiscent of two distinct types of proteins important for cell morphogenesis in yeast. Local-
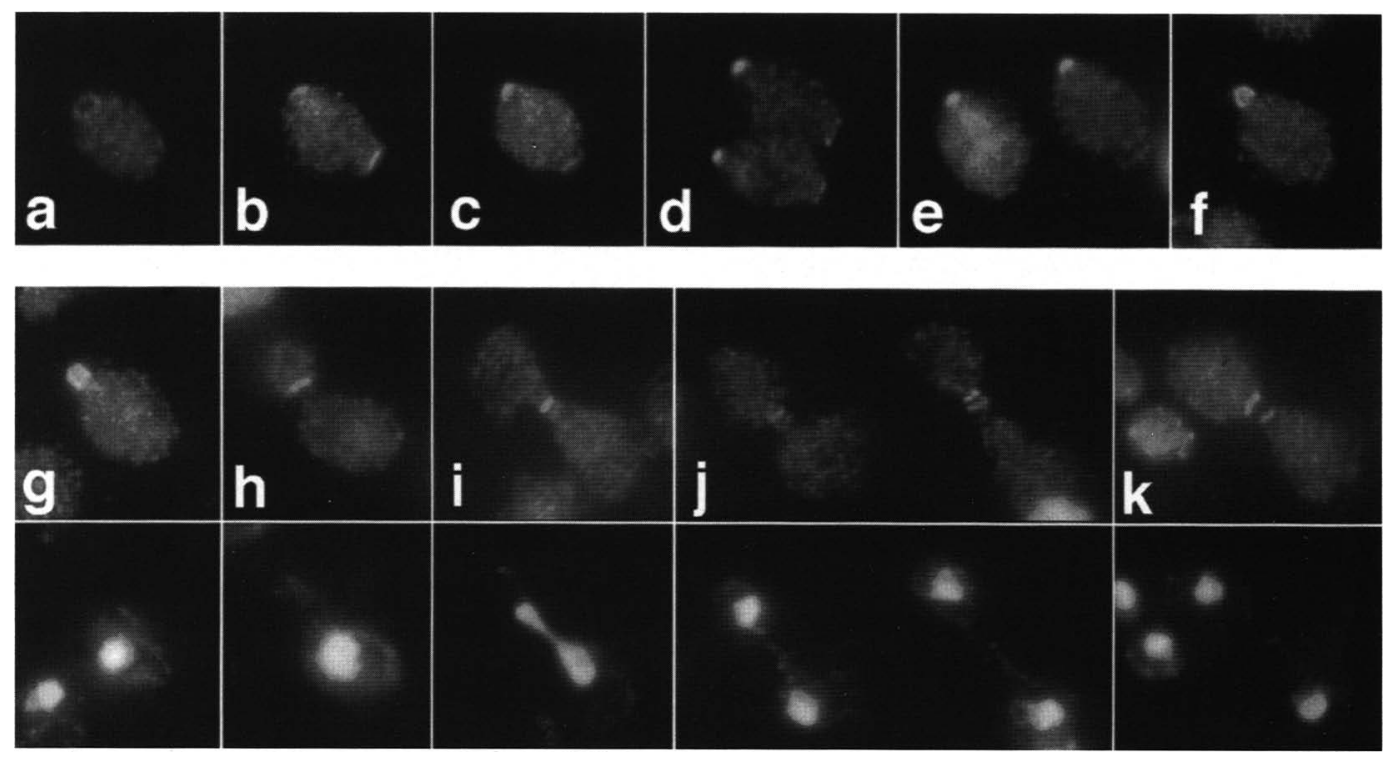

Figure 7. Distribution of Axl2p staining throughout the yeast cell cycle. Representative cells are depicted. $(a)$ An unbudded cell with ring staining: $(b, c)$ unbudded cells with a patch on one side of the cell (upper left) and a ring on the other side (the ring is difficult to see in this orientation, but is evident from analysis of different focal planes; (d) two cells with partial rings (lower right) and an emerging bud; $(e \mid$ two cells with staining at the incipient bud/emerging bud $\langle l e f t)$ and emerging bud $($ right $) ;(f)$ a small-budded cell showing staining around the bud periphery. Staining is also apparent at the neck but is not evident in this focal plane; $(g)$ a smallbudded cell with less intense staining around the cell periphery (suboptimal focal plane) and staining at the neck; $(h)$ a medium-sized budded cell with staining at the neck (note the staining is actually within the bud); $(i)$ mitotic cell with two rings at the neck; the stronger staining ring is most proximal to the bud, and faint staining is on the mother side; (j) Large-budded cells at late nuclear division (the left cell is similiar to the cell in $i$ except the nuclei have separated; the right cell also has separated nuclei and the two rings are of similar intensity); $(k)$ a cell at cytokinesis, and the rings appear to be separating (note the presence of a small unbudded cell with a ring in the same field). For cells such as those in $h-k$, the neck staining is in a ring similar to that shown in $a$ as determined by two criteria: (1) viewing different focal planes, and (2) examining cells with a different orientation. 
ization at the incipient bud site and nascent buds is similar to that of many polarity establishment proteins /see Discussion). The staining at the neck is similar to that reported for the neck filament proteins and for Bud3p and Bud4p. These latter two proteins appear at the neck in cells with a medium-sized bud and persist until after cytokinesis (Chant et al. 1995; S. Sanders and I. Herskowitz, pers. comm.).

To compare the localization of $\mathrm{Axl} 2 \mathrm{p}$ and Bud4p more closely, double indirect immunofluorescence experiments of Axl2p::HA cells with anti-HA antibodies and Bud4p antibodies were performed. Cells with emerging buds and small buds stained with anti-HA antibodies but did not stain with anti-Bud4p antibodies /data not shown). Conversely, cells that stain with anti-Bud4p antibodies do not stain at the bud periphery with anti-HA antibodies (data not shown). These results indicate that the period in the cell cycle in which Axl2p is no longer detectable at the cell periphery coincides with the point at which Bud4p localization begins.

Because the neck filament proteins Bud3p and Bud4p exhibit similar localization patterns during a significant portion of the cell cycle, and because each of these proteins is important for bud site selection in haploid cells, we examined the dependence of the neck filament-associated proteins and Axl2p upon one another using available mutants and antibodies. Cells in all stages of the cell cycle were examined. Axl2p::HA localized normally in a bud3 strain, and Cdc3p::HA and Bud4p localized in axl2 cells in a pattern indistinguishable from wild-type cells (data not shown). Thus, Axl2p does not require Bud3p, and $\mathrm{Cdc} 3 \mathrm{p}$ and $\mathrm{Bud} 4 \mathrm{p}$ do not require $\mathrm{Axl} 2 \mathrm{p}$ for localization to the neck region. Axl2p localization was also examined in strains containing a temperature-sensitive mutation in the CDC12 septin gene. At the restrictive temperature, Axl2p::HA was not detected at the neck region in cdc12-1 cells; however, localization to nascent and small buds was observed. Thus, Axl2p requires septins for localization to the neck region, but not for targeting to the incipient bud site.

\section{Axl2p levels are depleted in response to $\alpha$-factor}

During mating, haploid yeast cells override their axial budding pattern of polarized growth and form a growth projection at the site on the cell surface that senses the highest concentration of pheromone (Jackson and Hartwell 1990; Madden et al. 1992; Segall 1993; Chenevert 1994). One way to inactivate the axial site during mating might be to lose axial-specific components required for bud site selection. To explore this possibility, Axl2p levels were examined for up to $2 \mathrm{hr}$ following incubation in $5 \mu \mathrm{g} / \mathrm{ml}$ of $\alpha$-factor. Immunoblot analysis reveals a timedependent decrease in Axl2p levels not observed with either $\alpha$-tubulin or the $\alpha$-factor-inducible gene product Ciklp (Page and Snyder 1992) (Fig. 8). Immunofluorescence of MATa AXL2::3XHA haploid strains at 30-min intervals following incubation in an isotropic concentration of $5 \mu \mathrm{g} / \mathrm{ml}$ of $\alpha$-factor also revealed a steady decrease

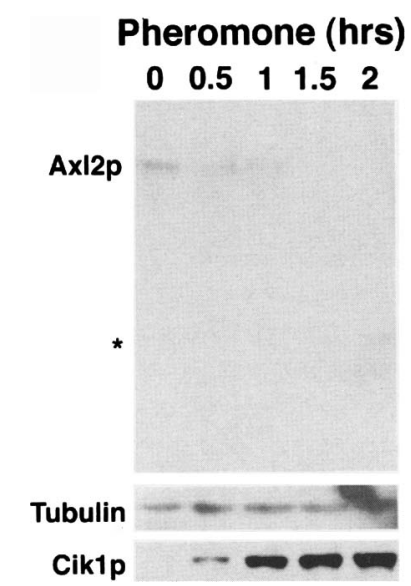

Figure 8. $\alpha$-Factor-dependent depletion of Axl2p. Y1163 cells were incubated in the presence of $5 \mu \mathrm{g} / \mathrm{ml}$ of $\alpha$-factor for the times indicated. The culture was supplemented with a second $\alpha$-factor treatment at the l-hr time point. Proteins were separated by gel electrophoresis, and immunoblots were prepared and probed with either 12CA5 (an anti-HA antibody), YOL1/34 (an anti- $\alpha$-tubulin monoclonal antibody), or anti-Ciklp antibodies. $\left({ }^{\star}\right)$ An endogenous yeast protein recognized by IZCAS.

in the intensity of Axl2p staining (data not shown). Unlike neck filament proteins, which stain as a broad/diffuse ring at the base of the mating projection during the entire process of projection formation and growth (Ford and Pringle 1991; Kim et al. 1991; Cdc3p::HA, data not shownl, Axl2p staining was not detected in shmoos. The lack of Axl2p staining is consistent with the phenotypes of $a x 12 \Delta$ strains and the hypothesis that Axl2p does not play a role during mating.

\section{AXL2 does not interact genetically with MSB2 and other polarity genes}

MSB2 encodes a protein of type I predicted topology that shares several additional features with Ax12p, including a long S/T-rich amino-terminal domain and a hydrophilic carboxy-terminal domain (Bender and Pringle 1992), as well as a putative SCB (Swi4/Swi6 cell cycle box) cell cycle expression element (Andrews and Herskowitz 1989) within its promoter. Moreover, MSB2 was isolated initially as a multicopy suppressor of the budding defect of the polarity establishment component CDC24 (Bender and Pringle 1989), yet cells display no obvious phenotype when MSB2 is disrupted (Bender and Pringle 1992). For these reasons, an MSB2 deletion was made in an axl2 null background (see Materials and methods) to examine any genetic interactions between these two genes. ax $12 \Delta, m s b 2 \Delta$, and $a x 12 \Delta$ msb2 $\Delta$ strains grew at identical rates and had similar cell morphologies at $30^{\circ} \mathrm{C}$ and $37^{\circ} \mathrm{C}$. Double mutants were also constructed between $a x l 2 \Delta$ and a variety of other deletion mutations in cell polarity genes, including spa2 $\Delta$, afr1s (Konopka

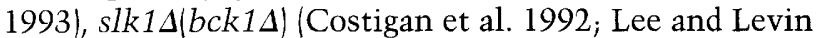

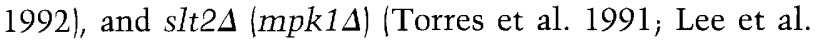


1993). In each of these cases, strains containing double mutations formed colonies at $25^{\circ} \mathrm{C}$ that were indistinguishable in size from single mutant strains.

\section{Discussion}

In this report we describe $A X L 2$, a novel gene identified as a multicopy suppressor of spa2d $c d c 10-10$ synthetic lethality in yeast. $A X L 2$ encodes a type I plasma membrane glycoprotein essential for the axial budding pattern of haploid cells. Axl2p is also important for bud morphogenesis and cytokinesis. Indirect immunofluorescence studies reveal that $\mathrm{Axl} 2 \mathrm{p}$ localizes to the incipient bud site and the periphery of small buds and to a ring at the neck. Axl2p is unique among all known bud site selection proteins, and polarity establishment proteins, as it is an integral membrane protein possessing both a cytoplasmic and extracellular domain.

\section{The subcellular distribution of $A \times 12 p$}

The subcellular distribution of Axl2p changes considerably throughout the cell cycle. Axl2p appears to localize as a peripheral patch at the incipient bud site in emerging buds and at the cell periphery in the buds of smallbudded cells. This localization pattern resembles that of many proteins involved in polarized cell growth in yeast, including Bem $1 \mathrm{p}, \mathrm{Cdc} 42 \mathrm{p}$, Cmdlp, Myo2p, and Spa2p (except that $\mathrm{Spa} 2 \mathrm{p}$ is also found in large-budded cells) (Snyder 1989; Snyder et al. 1991; Brockerhoff and Davis 1992; Sun et al. 1992; Ziman et al. 1993; Lillie and Brown 1994; Pringle et al. 1995). Of these polarity proteins, $\operatorname{Axl} 2 \mathrm{p}$ is most similar to $\mathrm{Cdc} 42 \mathrm{p}$, which localizes specifically to the edge of the bud, consistent with its plasma membrane localization (Ziman et al. 1993). Perhaps Axl2p interacts with one or more of these different polarized proteins.

In addition to its localization as a patch in emerging buds, and throughout the bud in small-budded cells, $\mathrm{Axl} 2 \mathrm{p}$ is also found as a ring at the neck in cells with medium- and large-sized buds. The period in the cell cycle at which Axl2p staining at the bud periphery is no longer detected is likely to be an important control step in the cell cycle. As shown by double immunofluorescence experiments, this is a period when Bud4p begins assembling at the neck region. The timing is also roughly coincident with the period when yeast cells switch from polarized cell growth in the bud to isotropic bud growth (Lew and Reed 1993). It is likely that this is a period when the $\mathrm{G}_{1} \mathrm{Cln} / \mathrm{Cdc} 28 \mathrm{p}$ kinase activity becomes inactivated and the $\mathrm{S} / \mathrm{G}_{2} \mathrm{Clb} / \mathrm{Cdc} 28 \mathrm{p}$ kinase is activated. Thus, Axl2p localization/delocalization may be directly regulated, perhaps at its potential Cdc28p phosphorylation site, by these kinase activities.

The localization pattern of $A x l 2 p$ at the neck has many similarities to those reported previously for the neck filament proteins, and particularly the neck filament-associated components Bud3p and Bud4p (Kim et al. 1991; Chant et al. 1995; S. Sanders and I. Herskowitz pers. comm.). However, there are also some interesting differences. Unlike other neck filament and associated components, $\mathrm{Axl} 2 \mathrm{p}$ is also present at the periphery of nascent and small buds. In addition, $\mathrm{Axl} 2 \mathrm{p}$ staining at the neck in medium- and many large-budded cells lies on the side of the neck closer to the bud than the mother, whereas the neck filament proteins Bud3p and Bud4p lie as a ring throughout the neck region (Kim et al. 1991; Chant et al. 1995; S. Sanders and I Herskowitz pers. comm.). One explanation for the asymmetric distribution of Axl2p at the neck is as follows: In budded cells $\mathrm{Axl} 2 \mathrm{p}$ is transported into the bud through polarized secretion; some of this material may diffuse until it finds its binding site at the neck filament complex. The $10-\mathrm{nm}$ filaments form a dense stack of continuous ring structures around the inside of the neck (Byers and Goetsch 1976a), which may obstruct Axl2p from diffusing and assembling on the mother side of the neck. When cells enter late nuclear division, secretion is expected to be directed to the neck region (Snyder et al. 1991; Madden et al. 1992; Lillie and Brown 1994). At this point, both the mother cell and the bud will accumulate secreted Axl2p, and weaker staining on the mother side of the neck is observed. Presumably, this process continues until both sides stain with equal intensity. By this mechanism, Axl2p might be preferentially distributed to the peripheral portions of the neck filament apparatus.

\section{Axl2p may participate in several aspects of budding/cytokinesis}

In addition to a bud site selection defect, axl2 $\Delta$ cells often possess elongated neck structures with diffuse chitin staining, buds that droop to one side of the neck, and a cytokinesis defect reminiscent of that observed in neck filament mutants. These morphological defects, which are observed in both haploid and diploid cells, suggest that Axl2p plays a role in early steps of bud formation and neck formation in both cell types. However, the role of $A x l 2 p$ appears to be specific to vegetative growth, because Axl2p levels are depleted rapidly in pheromone-treated cells and deletion of AXL2 does not reveal any obvious effect on shmoo morphology or mating efficiency.

The presence of extracellular and intracellular domains on $A x l 2 p$ raises the possibility that $A x 12 p$ may perform distinct roles on either side of the plasma membrane. The carboxy-terminal domain presumably participates in axial-specific bud site selection, perhaps by interacting with components important for this process (e.g., neck filament or associated proteins). It might also interact with neck filament-associated proteins to help coordinate cytokinesis. The amino-terminal domain of Axl2p may be involved in a cell wall-related process. In this respect, it may serve either as a neck-marking structural component onto which newly secreted extracellular components may assemble or, alternatively, it may associate with a cell wall polymer such as chitin or $\beta$-glucan to assist in anchoring $\mathrm{Axl} 2 \mathrm{p}$ to a fixed region of the cell surface. The presence of both intracellular and 
extracellular Axl2p domains can potentially link extracellular processes that occur during bud formation and cytokinesis to intracellular polarization events.

\section{Models for how Axl2p participates in bud site selection}

Like Bud3p and Bud4p, Ax12p participates in bud site selection in haploid cells, and AXL2 lies in the same epistasis group as BUD3. Interestingly, loss of AXL2 function does not reproduce the diploid pattern exactly; the efficiency of budding at proximal sites for haploid mothers $(\sim 50 \%)$ is less than that for diploid mothers $(\sim 83.5 \%)$. Similar results are observed for bud3s mutants (Table 1) and neck filament mutants (see Table II in Flescher et al. 1993). These data indicate that the diploid pattern is not exactly reflective of a loss of many axial pattern-specific bud site selection components. Possible explanations for why axl2 $\Delta$ or bud $3 \Delta$ haploid cells do not bud identically to that of diploid cells are $\{1\}$ the mutant components normally have a more important role in selecting the haploid proximal sites, whereas other components (e.g., Spa2p or Rvs167p; Snyder 1989; Bauer et al. 1993) are more important for selecting proximal sites in diploids; or (2) the haploid strains have a prolonged $G_{1}$ stage of the cell cycle, which could result in an increased chance of loss of the proximal cortical tag (or tag recognition) components in haploid mutants (Flescher et al. 1993).

Two models describing how Axl2p might participate in the axial budding pattern are shown in Figure 9. In both models Axl2p helps to direct the polarity establishment components to the new site. The left-hand model suggests that Axl2p is part of the neck filament complex that acts to localize another axial specific budding or bud site selection components to the $10-\mathrm{nm}$ filament ring. As a potential outer component of the ring (see above), it is ideally positioned to interact with components targeted to the new site. Axl2p localizes normally in bud3 null strains, and Bud $4 p$ components localize normally in axl2 $\Delta$ cells; thus, it is likely that Axl2p does not function directly through the Bud3p-Bud4p class of proteins to mediate bud site selection. Furthermore, Cdc3p localization is normal in axl2 null cells, suggesting that Axl2p is not solely responsible for localization of the neck filament proteins or maintenance of the ring. Axl2p might help recruit Rsrlp/Budlp or Axllp to the neck filament complex and/or maintain the stable association of Bud2p, Bud5p, or a presently unknown component of the cytokinesis tag site to help recruit growth components to the new bud site (Fig. 9).

An alternative model for how Axl2p participates in bud site selection is shown in Figure 9. The right-hand model views Axl2p as a component that recognizes the neck filament complex and helps direct new growth components to this site. Because Axl2p is an integral membrane protein, this would occur as part of a membrane vesicle. As with other models, Axl2p targeting might be mediated by Rsrlp/Budlp and could occur in conjunction with other bud site selection proteins such as Bud2p. Axl2p vesicles/complexes might contain polarity establishment proteins such as Bemlp, Cdc42p, and/or Spa2p. The initial Axl2p targeting event to establish the bud site could occur either when growth components are directed to the neck at cytokinesis or at the $\mathrm{G}_{1} / \mathrm{S}$ transition. Support for the model that Axl2p associates with neck filament complexes is its intimate association with the neck in medium- and large-budded cells.

This latter model has many similarities to those proposed for $\mathrm{v}$-SNARE/t-SNARE vesicle targeting during protein secretion (Ferro-Novick and Jahn 1994). Targeting of vesicles containing integral membrane v-SNARE proteins to membrane-bound $t$-SNAREs receptors is mediated by GTP-binding proteins (Rabs). For the righthand model in Figure 9, docking of Axl2p vesicles to membrane-associated proteins (the neck filament complex) might require Rsrlp/Bud lp and GTP hydrolysis. At present, we cannot distinguish between the two proposed models for Axl2p.

\section{Neck Filament Associated Protein}

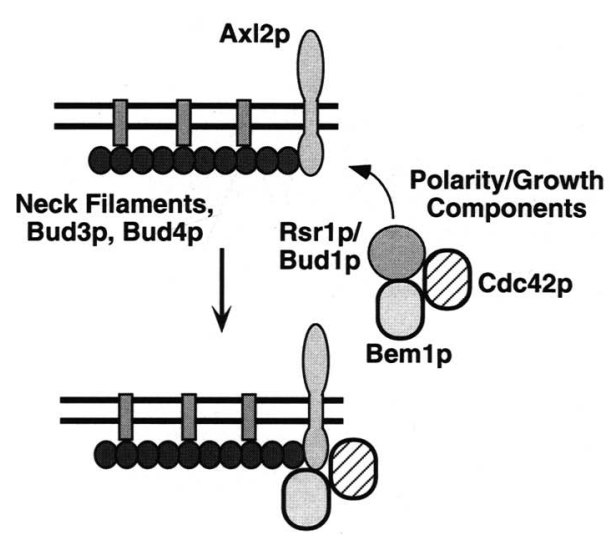

\section{Neck Filament Complex Recognition}

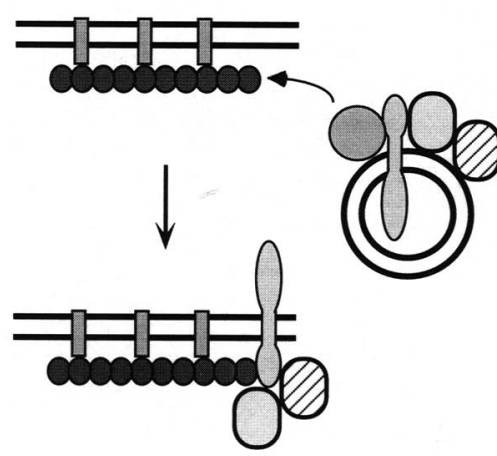

Figure 9. Models for how Axl2p participates in bud site selection. (Left) Axl2p is part of the neck filament complex (or tag) that helps recruit new growth components/polarity establishment components to the axial site. Alternatively \{right\}, Axl2p might be part of a complex that recognizes the neck filament complex (or tag) and helps target new growth components/ polarity establishment components to that site. The models are not mutually exclusive as homotypic Axl2p-Axl2p interactions could mediate this event. In both models, proper targeting presumably involves Rsrlp/Budlp. Candidate polarity proteins to be targeted to that site include Bemlp, Spa $2 p$, and Cdc42p or, most likely, a complex containing many of these components. 


\section{Loss of axial bud site selection components occurs during mating}

A presently unresolved issue is the ability of haploid cells to override the axial bud site selection program in response to mating pheromone and reorient polarized growth according to a pheromone gradient (Madden and Snyder 1992; Herskowitz et al. 1995). Reorientation could be achieved by (1) the loss or modification of axial specific-components; (2) pheromone-dependent expression or concentration of existing components, which can compete with the axial-specific complex for recruiting the polarized growth machinery; or $(3)$ both possibilities. Demonstration that Axl2p levels drop dramatically in response to $\alpha$-factor is consistent with a "molecular eraser" mechanism that contributes to the switch in growth site selection during mating (Chenevert et al. 1992; Madden and Snyder 1992). It will be interesting to determine whether other bud site selection components, for example, Bud3p and Bud4p, are also lost or modified after pheromone treatment.

\section{Similarities between polarized growth sites in yeast and other eukaroytes}

The yeast growth site has many similarities with analogous sites in other eukaryotes. At focal adhesion plaques, integrins (which are type I transmembrane proteins) help organize underlying cytoskeletal proteins, which in turn help organize the underlying actin cytoskeleton. Assembly of these complexes requires rho-type GTP-binding proteins (Clark and Brugge 1995, and references within) and protein kinase $\mathrm{C}$-dependent regulation. Budding yeast has many of the same components. The role of $\mathrm{Axl} 2 \mathrm{p}$ in establishing polarity sites in yeast may be analogous to that of the integrins. It and/or other transmembrane proteins are expected to help organize actin-binding proteins (Welch et al. 1994), and this process is likely to require rho-type GTP-binding proteins (Ridley 1995) and the PKC signaling pathway (Mazzoni et al. 1993; Costigan et al. 1994). Thus, the components and mechanisms important for bud site selection and polarity establishment in yeast are also expected to be of general importance to the events that occur in other eukaryotes.

\section{Materials and methods}

Yeast strains, media, and standard methods

Yeast strains used in this study are listed in Table 4. Genetic methods and growth media were as described in Guthrie and Fink (1991). For analysis of double mutants, $>20$ tetrads were dissected from double heterozygotes (e.g., axl2 $/ A X L 2$ spa2 $/$ / $S P A 2)$ and examined for growth at different temperatures. General cloning procedures were performed according to Sambrook et al. (1989). Yeast transformations were by the lithium acetate method of Ito et al. (1983).

\section{Isolation, subcloning, and sequencing of AXL2}

In a screen to be described elsewhere, a yeast genomic DNA library (Carlson and Botstein 1982) carried in the $2 \mu$ plasmid
YEp24 was transformed into strain Y831, and transformants were selected at $24^{\circ} \mathrm{C}$ on medium lacking uracil and containing limited adenine (Costigan et al. 1992, 1994). Four spa2d cdc1010-suppressing clones were found to contain the $A X L 2$ gene.

Plasmid p $2 \mu \mathrm{m}-A X L 2$ contains a $4.7-\mathrm{kb}$ insert; DNA sequence determined that this insert contains the 2469-bp ORF YIL140W, flanked upstream by 207 bp of the TCP1 3' sequence and downstream by the complete REV7 gene. The complete $R E V 7$ gene was subcloned as a $2.9-\mathrm{kb}$ HindIII-BglII fragment into the $2 \mu$ plasmid YEp352. This plasmid when transformed into Y831 failed to suppress spa2d cdc10-10 lethality, as judged by the absence of colony sectoring. Conversely, digestion of p2 $\mu \mathrm{m}-A X L 2$ with $S p h I$, and religation, which deletes the entire REV7 gene, including 843 bp of the YIL140W 3' sequence, suppressed spa2d cdc10-10 lethality to the same level as the original plasmid.

Approximately $1.0 \mathrm{~kb}$ of DNA sequence was determined from the 5' coding region of $A X L 2$ by the dideoxy sequencing method (Sanger et al. 1977). This segment partially overlapped with a large region on chromosome IX containing the REV7 gene (which lies 3' to $A X L 2$ ), which had been sequenced (Torpey et al. 1994). These two sequences yielded the entire $A X L 2$ coding region. This region was then sequenced further in its entirety as part of the chromosome IX sequencing project (accession no. Z38059| with no apparent differences. The GenBank accession number for $A X L 2$ is $\mathrm{U} 49845$.

\section{Disruption of AXL2, BUD3, and MSB2}

Deletion of $A X L 2, B U D 3$, and $M S B 2$ coding sequences was performed by substituting nearly the entire ORF (except for 0-12 codons, depending on the disruption; see below/ with DNA fragments containing either the HIS3 or TRP1 gene. An axl2$\triangle 1:: H I S 3$ null allele was generated by polymerase chain reaction (PCR), as described by Baudin et al. (1993), using the primers 5'-ACGATTTCCTGCTTCCAACATCTACGTATATCAAGAA GCATTCACTTACCGCGCGCCTCGTTCAGAATG-3' and 5' ${ }^{\prime}$-CGTTGCGTATAATCACAGCATTTCTGGGATGCGTCCGTGAATGTCCTTAACACTCTTGGCTCCTCTAGTA- ${ }^{\prime}$ and pRS303 as template to amplify the HIS3 gene. (The underlined portions of each primer correspond to the HIS3flanking sequence). The resulting PCR product contains the complete HIS3 gene flanked by $50 \mathrm{bp}$ of $A X L 2$ sequence upstream of the initiator ATG and by $51 \mathrm{bp}$ of the AXL2 3' sequence, including the $A X L 2$ TAA termination codon. When substituted at the $A X L 2$ locus, this DNA fragment deletes the entire $A X L 2$ gene, excluding the initiator ATG codon and the last 12 codons of $A X L 2$. The diploid yeast strain Y270 was transformed with this DNA fragment, and three independent transformants (Y1150, Y1151, and Y1152) that contained an axl2$\Delta 1: H I S 3$ allele substituted correctly at one of the two AXL2 loci were identified by PCR analysis. These strains were sporulated, and tetrads were dissected and analyzed.

Disruptions of $B U D 3$ and MSB2 were also generated in strain Y 270 by PCR and verified similarly as described above. A bud3::TRP1 disruption fragment was made using the primers 5'-CGTGTTCGGGCTGTTATCTGGTTGCTAA AAGAGTATATTTACACCTCACCAATGGCGCGTTTCGGTGATGACGGTG-3' and 5'-GTAAATGTATACATTGCATTAAATTAAAAAGAAAAAAAAAATCAATAAAACACTCAGGGTGATGGTTCACGTAGTGGGC-3' and pRS304 as template DNA. (The underlined portion of each primer corresponds to TRP1flanking sequence). This PCR product contains the TRP1 gene flanked on one side by the BUD3 ATG and $51 \mathrm{bp}$ of the BUD 3 upstream sequence and by the $B U D 3$ TGA termination codon 
Table 4. Strain list

\begin{tabular}{|c|c|c|}
\hline Strain & Genotype & Source \\
\hline Y270 & 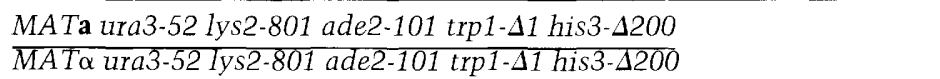 & \\
\hline Y602 & 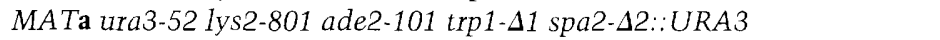 & \\
\hline Y782 & 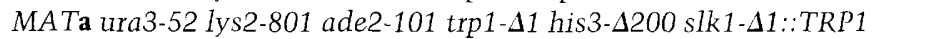 & \\
\hline Y783 & MATa ura3-52 lys2-801 ade2-101 leu2- $\Delta 98$ his3- $\Delta 200$ slt2- $\Delta 10::$ LEU2 & \\
\hline Y831 & 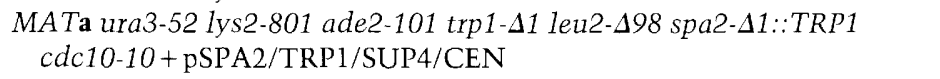 & $\begin{array}{l}\text { J. Chant (Harvard } \\
\text { University, Cambridge, }\end{array}$ \\
\hline Y837 & MATa ura3-52 trp1 /his4 HMR $H M L \alpha$ can1 MAL2 bud5::URA3 & Massachusetts) \\
\hline Y838 & MA Ta ura3-52 lys2 ade2 his7 trp1-289 cdc3-1 & \\
\hline Y839 & MATa ura3-52 lys2 ade2 his7 tyr1 trp1-289 cdc10-1 & \\
\hline Y840 & MATa ura3-52 lys2 ade2 his7 tyr1 trp1-289 leu2 cdc11-1 & \\
\hline Y841 & MATa ura3-52 lys2 ade2 his7 trp1-289 cdc12-1 & \\
\hline Y1150- & 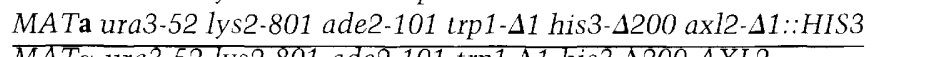 & \\
\hline $\begin{array}{l}Y 1152 \\
\text { Y1153 }\end{array}$ & 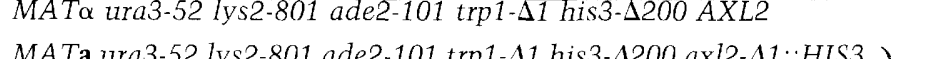 & \\
\hline $\begin{array}{l}Y 1153 \\
\text { Y1154 }\end{array}$ & 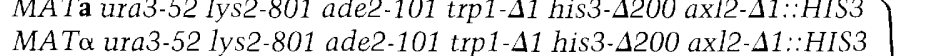 & \\
\hline Y1155 & MATa ura3-52 lys2-801 ade2-101 trp1-41 his3-4200 ALX2 & segregants from a \\
\hline Y1156 & MAT $\alpha$ ura3-52 lys2-801 ade2-101 irp1-41 his3-4200 AXL2 & Y1150 tetrad \\
\hline Y1157 & 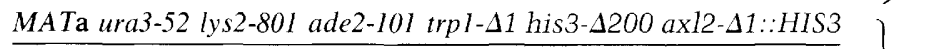 & Diploid from \\
\hline Y1158 & 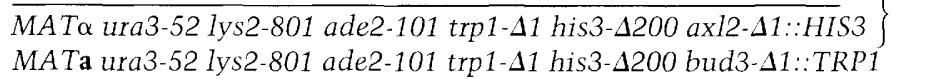 & Y1153 × Y1154 \\
\hline Y1159 & $\left.\begin{array}{l}\text { MATa ura3-52 lys2-801 ade2-101 trp1- } \Delta 1 \text { his } 3-\Delta 200 \\
\text { axl2- } \Delta 1:: H I S 3 \text { bud3- } \Delta 1:: T R P 1\end{array}\right\}$ & $\begin{array}{l}\text { Spore from } \\
\text { Y1154 × Y1158 }\end{array}$ \\
\hline Y1160 & 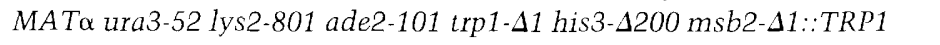 & \\
\hline Y1161 & 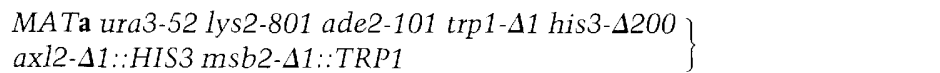 & $\begin{array}{l}\text { Spore from } \\
\text { Y1153 × Y1160 }\end{array}$ \\
\hline Y1162 & 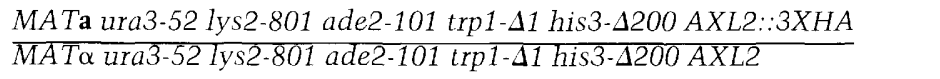 & \\
\hline $\begin{array}{l}\text { Y1163 } \\
\text { Y1164 }\end{array}$ & 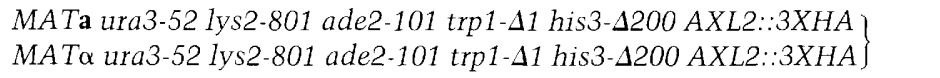 & $\begin{array}{l}\text { Spore progeny from two } \\
\text { separate Y1162 tetrads }\end{array}$ \\
\hline Y1165 & 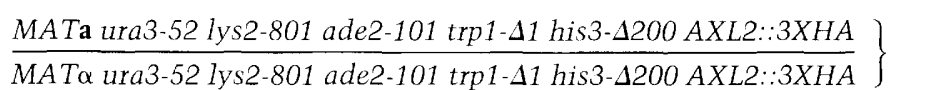 & $\begin{array}{l}\text { Diploid from } \\
\text { Y1 } 163 \times \text { Y } 1164\end{array}$ \\
\hline Y1166 & $\left.\begin{array}{l}\text { MATa ura3-52 lys2-801 ade2-101 trp1- }-41 \text { his3- } \Delta 200 \\
\text { bud3- } \Delta 1:: T R P 1 \text { AXL2::3XHA }\end{array}\right\}$ & $\begin{array}{l}\text { Spore from } \\
\text { Y1164 × Y1158 }\end{array}$ \\
\hline Y885 & $\begin{array}{l}\text { MATa ura3 leu2 his } 3 \text { bud1::URA3 } \\
\text { MAT } \alpha \text { ura3 leu2 his } 3 \text { bud1::URA3 }\end{array}$ & $\begin{array}{l}\text { A. Bender (Indiana University, } \\
\text { Bloomington) }\end{array}$ \\
\hline Y1167 & 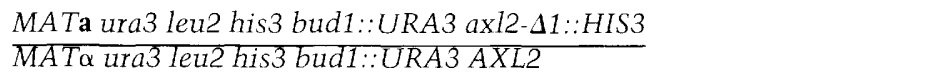 & \\
\hline Y1168 & MATa ura3 leu2 his3 bud1::URA3 axl2- $11::$ HIS3 & \\
\hline Y1169 & MATa ura3 leu2 his3 bud1::URA3 AXL2 & \\
\hline Y1170 & $\frac{\text { MATa ura3 leu2 his3 lys2 trp1 ade2 }}{\text { MAT } \alpha \text { ura3 leu2 his3 lys2 trp1 ade2 }}$ & \\
\hline Y1171 & MAT $\alpha$ ura3 leu2 his3 lys2 trp1 ade2 CDC3::3XHA & \\
\hline Y1172 & MATa ura3 leu2 his3 lys2 trp1 ade2 CDC3::3XHA axI2- $1::$ HIS3 & spore from Y1171 × Y1153 \\
\hline JK27 & MATa ura3 lys2 ade2-1 trp1 his4-580 leu2 cry1 SUP4-3ts afr1-A::URA3 & $\begin{array}{l}\text { J. Konopka (State University } \\
\text { of New York, Stony Brook) }\end{array}$ \\
\hline
\end{tabular}

and 54 bp of the BUD 3 downstream sequence. An msb2::TRP1 PCR product containing 58 bp of the MSB2 sequence immediately upstream of the putative initiator $\mathrm{ATG}$, the complete TRP1 gene, and $53 \mathrm{bp}$ of MSB2 sequence, including the TGA termination codon, was generated using the primers $5^{\prime}$ CCACCTCGTTTCCTATTTTTATTGACTTTTCATTAGGCTTCCTAATTATACCCATCTAGCGCGTTTCGGTGATGACGGTG- ${ }^{\prime}$ and 5'-GCGGAGAAAGTCTCTGCAGACATTGCTA TCAAACTTCGTTCCAACCCAGGGAGGGGTGATGGTTCACGTAGTGGGC-3'. Substitution of this DNA frag- ment at the MSB2 locus deletes the entire MSB2 ORF except for its final 7 codons.

Production of antibodies to Axl2p

The AXL2 3' sequence (nucleotides 1590-2472) encoding the entire carboxy-terminal portion of the protein following the putative transmembrane domain was amplified by PCR using the primers 5'-CGCGGATCCCAGACGCAGAAGGAAAATCCAGAC-3' and 5'-CCGGAATTCTCACAGCATTTCTGGGAT- 


\section{Production of antibodies to Axl2p}

The AXL2 3' sequence (nucleotides 1590-2472) encoding the entire carboxy-terminal portion of the protein following the putative transmembrane domain was amplified by PCR using the primers 5'-CGCGGATCCCAGACGCAGAAGGAAAATCCAGAC-3' and 5'-CCGGAATTCTCACAGCATTTCTGGGATGCGT-3' (BamHI and EcoRI sites added to the ends of the oligonucleotides are underlined) and $\mathrm{p} 2 \mu \mathrm{m}-A X L 2$ as template DNA. This PCR product was subcloned into pGEXl as a $B a m H I-E c o R I$ fragment; the resulting construct places $A X L 2$ coding sequences in-frame and downstream of GST. The GstAxl2p fusion protein was expressed in Escherichia coli strain B117 and purified as described (Smith and Johnson 1988). The purifed protein was injected into a rabbit (Pocono Rabbit Farm and Laboratory, Canadensis, PA). A primary injection was followed by four boosts spaced 2 weeks apart. Each immunization consisted of $200 \mu \mathrm{g}$ of protein applied subcutaneously in 10 locations. Both preimmune and immune antibodies were affinity purified as described (Snyder 1989).

\section{Epitope tagging the $\mathrm{AXL} 2$ and $\mathrm{CDC} 3$ genomic loci}

A 1.5 -kb portion of the $A X L 23$ ' sequence was amplified by PCR using the primers 5'-CCGGAATTCTATGATACTTATGGTGATGTGA-3' (an EcoRI site is underlined) and 5'-CGCGGATCCttaGCGGCCGCGCAGCATTTCTGGGATGCGTCCGTGAAT-3' (BamHI and NotI sites are in italics and bold, respectively; the AXL2 stop codon is in lowercase letters) and subcloned as a BamHI-EcoRl fragment into YIp5 (Botstein et al. 1979). This plasmid was linearized at the NotI site immediately upstream of the AXL2 stop codon, allowing a 111-bp NotI fragment encoding three copies of the HA epitope to be cloned into this site. The resulting plasmid was linearized at the AXL2 insert HindIII site and transformed into $\mathrm{Y} 270$, producing an intact AXL2::3XHA allele. Correct integration of this plasmid at the AXL2 locus was determined by PCR analysis. This allele is linked tightly with the URA3 gene of YIp5 and segregates $2^{+}$: $2^{-}$upon sporulation and tetrad analysis of $A X L 2:: 3 X H A / A X L 2$ heterozygotes. Analysis of the budding pattern of haploid AXL2::3XHA strains demonstrated this allele to be indistinguishable from wild type.

A CDC3:: $3 X H A$ allele was constructed following the PCR epitope-tagging method of Schneider et al. (1995). Primers 5'CACGACAACTGA ACGATTACATCGGCCTATAATACGTTGCCATGAGTTTAAGGGAACAAAAGCTGG-3' and 5'TGACGCTCTTCTTGTTCCGGGTCCTGCTTAATGGACACTTGTTCCTCCTTCTGTA GGGCGAATTGGG-3' were used to amplify a region of pMPY-3XHA; the resulting $1.5-\mathrm{kb}$ PCR product contains the complete URA3 gene flanked by direct repeats encoding the three copies of the HA epitope, and in turn is flanked by 50 bp of $C D C 3$ sequence. This DNA fragment was transformed into Y270 and integrated 9 bp downstream and in-frame with the CDC3 ATG. Correct integration was determined by PCR analysis. To circumvent difficulties associated with using this method on an essential gene, YEp13-CDC3 was transformed into a $c d c 3:: 3 X H A / C D C 3$ diploid isolate and sporulated, and haploid strains containing both the $c d c 3$ epitope insertion allele and YEp13-CDC3 were isolated. Several such isolates were streaked onto 5-fluoro-orotic acid (5-FOA) plates to select for ura 3 cells that have recombined between the two repeated epitopes and lost the URA3 gene, leaving a single in-frame 3XHA-encoding epitope sequence at the $5^{\prime}$ end of the $C D C 3$ gene. Y1170 is one such isolate that has been cured of YEp13-CDC3 and exhibits a pattern of localization indistinguishable from authentic Cdc3p (Kim et al. 1991).

\section{Yeast immunoblot analyses}

Strains Y1153 and Y1155, containing either $\mathrm{p} 2 \mu \mathrm{m}-A X L 2$ or YEp24, were grown in $10 \mathrm{ml}$ of synthetic complete medium lacking uracil ( $\mathrm{SC}-$ Ura) to mid-log phase $\left(\mathrm{OD}_{600}=1.2\right.$ ). Cells were washed and lysed using glass beads in $200 \mu \mathrm{l}$ of $10 \mathrm{~mm}$ Tris- $\mathrm{HCl}(\mathrm{pH} 7.5)$ containing the protease inhibitors phenylmethanesulfonyl fluoride ( $\mathrm{mm})$, leupeptin $(10 \mu \mathrm{g} / \mathrm{ml})$, pepstatin $(10 \mu \mathrm{g} / \mathrm{ml})$, aprotinin $(20 \mu \mathrm{g} / \mathrm{ml})$, antipain $(20 \mu \mathrm{g} / \mathrm{ml})$, and chemostatin $(20 \mu \mathrm{g} / \mathrm{ml})$. Lysates were centrifuged for $5 \mathrm{~min}$ at $1000 \mathrm{~g}$ to remove unlysed cells, and supernatants were divided into a total cell lysate or fractionated into a supernatant and pellet fraction following centrifugation at $100,000 \mathrm{~g}$ for $15 \mathrm{~min}$ at room temperature. These samples were resuspended to a final volume of $500 \mu \mathrm{l}$ in Laemmli sample buffer (Sambrook et al. 1989 ) and boiled for $5 \mathrm{~min}$ prior to loading onto an $8.0 \%$ acrylamide minigel containing SDS. After electophoresis, proteins were blotted onto Immobilon-P (Millipore), probed with affinity-purified anti-Axl2p antibodies, and detected using goat antirabbit alkaline phosphatase-conjugated antibodies and Lumiphos (Boehringer Mannheim) detection reagents.

Tunicamycin treatment was performed on a $10-\mathrm{ml}$ culture of Y1153, containing $\mathrm{p} 2 \mu \mathrm{m}-A X L 2$, grown in SC-Ura to mid-log phase. Cells were concentrated fourfold in fresh SC-Ura, grown for an additional $30 \mathrm{~min}$, and then treated with a final concentration of $10 \mu \mathrm{g} / \mathrm{ml}$ of tunicamycin (Sigma) for $30 \mathrm{~min}$ at $30^{\circ} \mathrm{C}$; a control culture was treated identically but without tunicamycin. These samples were processed for immunoblot analysis as described above.

Axl2p::3XHA levels were assessed after $\alpha$-factor treatment as follows: The MATa strain Y1163 was grown in YPAD to early log phase $\left[\mathrm{OD}_{600}=0.4\left(\sim 5 \times 10^{6} \mathrm{cells} / \mathrm{ml}\right)\right]$, and incubated with shaking at $30^{\circ} \mathrm{C}$ with $5 \mu \mathrm{g} / \mathrm{ml}$ of $\alpha$-factor (Sigma). Aliquots $\left(\sim 1 \times 10^{7}\right.$ cells $)$ were collected at $30-\mathrm{min}$ intervals, washed in 10 $\mathrm{mm}$ Tris- $\mathrm{HCl}(\mathrm{pH} 7.5)$, and lysed with glass beads in $200 \mu \mathrm{l}$ of Laemmli sample buffer (Sambrook et al. 1989) containing protease inhibitors. Cultures were supplemented with a second addition of $5 \mu \mathrm{g} / \mathrm{ml}$ of $\alpha$-factor at the 1 -hr time point. Microscopic examination of the cultures revealed that $>90 \%$ of the cells were arrested as unbudded cells at the 1.5 and 2.0 -hr time points. Immunoblots were performed as described above using mAb 12CA5 (Wilson et al. 1984; purchased from BABCO), YOLl/34 (a mouse monoclonal antibody against yeast $\alpha$-tubulin; Kilmartin et al. 1982), and affinity-purified rabbit antiCik1p antibodies (Page and Snyder 1992). The primary antibodies were detected with goat anti-mouse and goat anti-rabbit alkaline phosphatase-conjugated antibodies. To improve detection of Axl2p::3XHA, the more sensitive fluorescent substrate for alkaline phosphatase, CDP-STAR (Boehringer Mannheim), was used.

\section{Membrane fractionation and extraction}

$50-\mathrm{ml}$ culture of $\mathrm{Y} 1153$ containing $\mathrm{p} 2 \mu \mathrm{m}-A X L 2$ was grown to mid-log phase in SC-Ura, washed, and resuspended in $10 \mathrm{~mm}$ Tris- $\mathrm{HCl}(\mathrm{pH} 7.5)$ containing protease inhibitors, and lysed with glass beads. Lysed material was centrifuged at $1000 \mathrm{~g}$ to remove unlysed cells, and the supernatant was divided into five fractions and processed according to Roemer et al. (1994). Immunoblot analysis was performed using a 1:2000 dilution of affinitypurified anti-Axl2p antibody, and 1:1500 dilution of alkaline phosphatase-conjugated goat anti-rabbit antibodies (Jackson Immunoresearch) and detected using Lumiphos developing reagent.

Proteinase K protection experiments

The proteinase $\mathrm{K}$ protection experiment was performed as out- 
lined by Trueheart and Fink (1989), but with the following modifications. A $60-\mathrm{ml}$ culture of Y1154 containing p $2 \mu \mathrm{m}-A X L 2$ was grown to mid-log phase in SC-Ura. Cells were resuspended and divided into six 100- $\mu$ l fractions in lyticase buffer (1.2 $\mathrm{M}$ sorbitol, $25 \mathrm{~mm}$ Tris- $\mathrm{HCl}$ at $\mathrm{pH} 7.5,2 \mathrm{~mm} \mathrm{MgCl}_{2}, 0.5 \%$ 2-mercaptoethanol), and treated according to the matrix of conditions described in Figure 5. Zymolyase 100T (Seikagaku, Japan) was added to a concentration of $5 \mu \mathrm{g} / \mathrm{ml}$ and incubated for $15 \mathrm{~min}$ at $37^{\circ} \mathrm{C}$. Triton $\mathrm{X}-100$ was then added to $0.1 \%$, and proteinase $\mathrm{K}$ (Boehringer) was added to $50 \mu \mathrm{g} / \mathrm{ml}$ and incubated for $10 \mathrm{~min}$ at room temperature. Protease digestions were stopped by the immediate addition of $2 \times$ Laemmli protein sample buffer containing twice the concentrations of protease inhibitors described above and boiled 5 min prior to loading onto a $15 \%$ acrylamide-SDS minigel.

\section{Indirect immunofluorescence}

Indirect immunofluorescence was performed as outlined by Gehrung and Snyder (1990) and Pringle et al. (1991). Primary antibody incubations were performed overnight using $\mathrm{mAb}$ 12CA5, a mouse anti-HA epitope (BABCO, Richmond, CA) or affinity-purified rabbit anti-Axl2p antibody. For detection of primary antibodies, CY3-conjugated goat anti-mouse antibodies or CY3-conjugated goat anti-rabbit antibodies (Jackson Immunoresearch, West Grove, PA) were incubated with samples for $3 \mathrm{hr}$. Cells were washed once with PBS/BSA, once with PBS/BSA containing $0.1 \%$ NP-40 and $0.1 \%$ SDS, once with PBS/BSA containing $0.1 \%$ NP-40, and once with PBS/BSA. Hoechst 33258 was used to visualize nuclear and mitochondrial DNA.

\section{Morphological and budding pattern analysis}

Budding pattern analysis was performed on mid-log phase cells fixed in formaldehyde to $3.7 \%(\mathrm{vol} / \mathrm{vol})$ for $30 \mathrm{~min}$ while rotating at $30^{\circ} \mathrm{C}$. Cells were then washed three times and resuspended in $10 \mathrm{~mm}$ Tris- $\mathrm{HCl}(\mathrm{pH} \mathrm{7.5)}$, to which Fluorescent Brightener 28 (Calcofluor, Sigma) was added to a final concentration of $5 \mu \mathrm{g} / \mathrm{ml}$ to visualize bud and birth scars. Quantitation of cells was performed according to the classification scheme of Madden and Snyder (1992).

Quantitation of cytokinesis defects was performed according to Flescher et al. (1993), in which the total number of connected buds and cell bodies was counted per chain. Care was taken to ensure that cells within a chain were connected. For quantitation of spheroplasts, cells were digested with $5 \mu \mathrm{g} / \mathrm{ml}$ of $\mathrm{Zy}$ molyase for $30 \mathrm{~min}$ at $37^{\circ} \mathrm{C}$, placed on a polylysine-coated slide for $10 \mathrm{~min}$, washed three times with PBS/BSA, and scored as above.

\section{Acknowledgments}

We thank S. Sanders and I. Herskowitz for generously providing anti-Bud4p antibodies, D. Drubin for the anti-actin antibodies, S. Erdman for carrying out the axl2 $\Delta$ quantitative matings, B. Futcher for providing the triple HA tag plasmid, and Y. Barrell, J. Barrett, S. Erdman, and L. Vallier for critical comments on the manuscript. T.R and K.M. were supported by a Medical Research Council postdoctoral fellowship and Howard Hughes predoctoral fellowship, respectively. This research was supported by National Institutes of Health grants GM36494 and GM52197.

The publication costs of this article were defrayed in part by payment of page charges. This article must therefore be hereby marked "advertisement" in accordance with 18 USC section 1734 solely to indicate this fact.

\section{References}

Adames, N., K. Blundell, M. Ashby, and C. Boone. 1995. Role of yeast insulin-degrading enzyme homologs in propheromone processing and bud site selection. Science 270: 464-467.

Alvarez, E., I. Northwood, F. Gonzalez, D. Latour, A. Seth, C. Abate, T. Curran, and R. Davis. 1991. Pro-Leu-Ser/Thr-Pro is a consensus primary sequence for substrate protein phosphorylation. J. Biol. Chem. 266: 15277-15285.

Andrews, B. and I. Herskowitz. 1989. Identification of a DNA binding factor involved in cell cycle control of the HO gene. Cell 57: 21-29.

Baudin, A., O. Ozier-Kalogeropoulos, A. Denouel, F. Lacroute, and C. Cullin. 1993. A simple and efficient method for direct gene deletion in Saccharomyces cerevisiae. Nucleic Acids Res. 21: 3329-3330.

Bauer, F., M. Urdaci, M. Aigle, and M. Crouzet. 1993. Alteration of a yeast $\mathrm{SH} 3$ protein leads to conditional viability with defects in cytoskeletal and budding patterns. Mol. Cell. Biol. 13: $5070-5084$.

Bender, A. and J.R. Pringle. 1989. Multicopy suppression of the $c d c 24$ budding defect in yeast by CDC42 and three newly identified genes including the ras-related gene RSR1. Proc. Natl. Acad. Sci. 86: 9976-9980.

—_ 1992. A Ser/Thr-rich multicopy suppressor of a $c d c 24$ bud emergence defect. Yeast 8: 315-323.

Botstein, D., S.C. Falco, S.E. Stewart, M. Brennan, S. Scherer, D.T. Stinchcomb, K. Struhl, and R.W. Davis. 1979. Sterile host yeasts (SHY): A eukaryotic system of biological containment for recombinant DNA experiments. Gene 8: 1724.

Brockerhoff, S.E. and T.N. Davis. 1992. Calmodulin concentrates at regions of cell growth in Saccharomyces cerevisiae. I. Cell Biol. 118: 619-629.

Byers, B. 1981. Cytology of the yeast life cycle. In The molecular biology of the yeast Saccharomyces: Life cycle and inheritance. (ed. J.N. Strathern, E. Jones, and J. Broach), pp. 59-96. Cold Spring Harbor Laboratory, Cold Spring Harbor, NY.

Byers, B. and L. Goetsch. 1976a. A highly ordered ring of membrane-associated filaments in budding yeast. I. Cell Biol. 69: $717-721$

- $1976 \mathrm{~b}$. Loss of the filamentous ring in cytokinesis-defective mutants of budding yeast. J. Cell Biol. 70: 35a.

Carlson, M. and D. Botstein. 1982. Two differentially regulated mRNAs with different $5^{\prime}$ ends encode secreted and intracellular forms of yeast invertase. Cell 28: 145-154.

Chant, J. 1994. Cell polarity in yeast. Trends Genet. 10: 328333.

Chant, J. and I. Herskowitz. 1991. Genetic control of bud-site selection in yeast by a set of gene products that comprise a morphogenetic pathway. Cell 65: 1203-1212.

Chant, J. and J.R. Pringle. 1995. Patterns of bud site selection in the yeast Saccharomyces cerevisiae. I. Cell Biol. 129: 751765.

Chant, J., K. Corrado, J.R. Pringle, and I. Herskowitz. 1991. The yeast BUD5 gene, which encodes a putative GDP-GTP exchange factor, is necessary for bud-site selection and interacts with bud-formation gene BEM1. Cell 65: 1213-1224.

Chant, J., M. Mischke, E. Mitchell, I. Herskowitz, and J.R. Pringle. 1995. Role of Bud3p in producing the axial budding pattern of yeast. I. Cell Biol. 129: 767-778.

Chen, W., H.H. Lim, and L. Lim. 1993. The CDC42 homolog 
from C. elegans. I. Biol. Chem. 268: 13280-13285.

Chenevert, J. 1994. Cell polarization directed by extracellular cues in yeast. Mol. Biol. Cell. 5: 1169-1175.

Chenevert, J., K. Corrado, A. Bender, J. Pringle, and I. Herskowitz. 1992. A yeast gene (BEM1) necessary for cell polarization whose product contains two SH3 domains. Nature 356: 7779.

Cheng, N., C. Kirby, and K. Kemphues. 1994. Control of cleavage spindle orientation in Caenorhabditis elegans: The role of the genes par-2 and par-3. Genetics 139: 549-559.

Chenn, A. and S.K. McConnell. 1995. Cleavage orientation and the asymmetric inheritance of Notchl immunoreactivity in mammalian neurogenesis. Cell 82: 631-641.

Cid, V., A. Duran, F.D. Rey, M. Snyder, C. Nombela, and M. Sanchez. 1995. Molecular basis of cell integrity and morphogenesis in Saccharomyces cerevisiae. Microbiol. Rev. 59: 345-386.

Clark, E. and J. Brugge. 1995. Integrins and signal transduction pathways: The road taken. Science 268: 233-239.

Cohen, G.B., R. Ren, and D. Baltimore. 1995. Modular binding domains in signal transduction proteins. Cell 80: 237-248.

Costigan, C. and M. Snyder. 1996. Cell polarity in the budding yeast, Saccharomyces cerevisiae. Adv. Mol. Cell Biol. (in press).

Costigan, C., S. Gehrung, and M. Snyder. 1992. A synthetic lethal screen identifies SLK1, a novel protein kinase homolog implicated in yeast cell morphogenesis and cell growth. Mol. Cell. Biol. 12: 1162-1178.

Costigan, C., D. Kolodrubetz, and M. Snyder. 1994. NHPGA and NHP6B, which encode HMGl-like proteins, function downstream in the yeast SLT2 MAPK pathway. Mol. Cell. Biol. 14: $2391-2403$.

DiDomenico, B.J., N.H. Brown, J. Lupisella, J.R. Greene, M. Yanko, and Y. Koltin. 1994. Homologs of the yeast neck filament associated genes: Isolation and sequence analysis of Candida albicans CDC3 and CDC10. Mol. \& Gen. Genet. 242: 689-698.

Drubin, D. 1991. Development of cell polarity in budding yeast. Cell 65: 1093-1096.

Fares, H., M. Peifer, and J.R. Pringle. 1995. Localization and possible functions of Drosophila septins. Mol. Biol. Cell 6: $1843-1859$.

Ferro-Novick, S. and R. Jahn. 1994. Vesicle fusion from yeast to man. Nature 370: 191-193.

Field, C. and R. Schekman. 1980. Localized secretion of acid phosphatase reflects the pattern of cell surface growth in Saccharomyces cerevisiae. I. Cell Biol. 86: 123-128.

Flescher, E.G., K. Madden, and M. Snyder. 1993. Components required for cytokinesis are important for bud site selection in yeast. I. Cell Biol. 122: 373-386.

Ford, S. and J. Pringle. 1991. Cellular morphogenesis in the Saccharomyces cerevisiae cell cycle: Localization of the CDC11 gene product and the timing of events at the budding site. Dev. Genet. 12: 281-292.

Freifelder, D. 1960. Bud position in Saccharomyces cerevisiae. J. Bacteriol. 124: 511-523.

Fugita, A., C. Oka, Y. Arikawa, T. Katagal, A. Tonouchi, S. Kuhara, and Y. Misumi. 1994. A yeast gene necessary for bud-site selection encodes a protein similar to insulin-degrading enzymes. Nature 372: 567-569.

Fujiki, Y., A. Hubbard, S. Fowler, and P. Lazarow. 1982. Isolation of intracellular membranes by means of sodium carbonate treatment: Application of endoplasmic reticulum. I. Cell Biol. 93: 97-102.

Gehrung, S. and M. Snyder. 1990. The SPA2 gene of Saccharomyces cerevisiae is important for pheromone-induced mor- phogenesis and efficient mating. I. Cell Biol. 111: 14511464.

Goud, B., A. Salminen, N.C. Walworth, and P.J. Novick. 1988. A GTP-binding protein required for secretion rapidly associates with secretory vesicles and the plasma membrane in yeast. Cell 53: 753-768.

Guthrie, C. and G.R. Fink. 1991. Guide to yeast genetics and molecular biology. Methods Enzymol. 194: 933.

Haarer, B. and J.R. Pringle. 1987. Immunofluorescence localization of the Saccharomyces cerevisiae $\mathrm{CDCl} 2$ gene product to the vicinity of the $10 \mathrm{~nm}$ filaments in the mother-bud neck. Mol. Cell. Biol. 7: 3678-3687.

Hartwell, L.H., R.K. Mortimer, J. Culotti, and M. Culotti. 1973. Genetic control of the cell division cycle in yeast. V. Genetic analysis of $c d c$ mutants. Genetics 74: 267-286.

Hayashibe, M. and S. Katohda. 1973. Initiation of budding and chitin-ring. J. Gen. Appl. Microbiol. 19: 23-39.

Herskowitz, I., H.-O. Park, S. Sanders, N. Valtz, and M. Peter. 1995. Programming of cell polarity in budding yeast by endogenous and exogenous signals. Cold Spring Harbor Symp. Quant. Biol. (in press).

Hicks, J.B., J.N. Strathern, and I. Herskowitz. 1977. Interconversion of yeast mating types. III. Action of the homothallism ( $\mathrm{HO})$ gene in cells homozygous for the mating type locus. Genetics 85: 395-405.

Hyman, A.A. and J.G. White. 1987. Determination of cell division axes in the early embryogenesis of Caenorhabditis elegans. I. Cell Biol. 105: 2123-2135.

Ito, H., Y. Fukuda, K. Murata, and A. Kimura. 1983. Transformation of intact yeast cells treated with alkali cations. $/$. Bacteriol. 153: 163-168.

Jackson, C.L. and L.H. Hartwell. 1990. Courtship in S. cerevisiae: Both cell types choose mating partners by responding to the strongest pheromone signal. Cell 63: 1039-1051.

Johnston, L. and N. Lowndes. 1992. Cell cycle control of DNA synthesis in budding yeast. Nucleic Acids Res. 20: 24032410 .

Johnston, L., N. Lowndes, A. Johnston, and A. Sugino. 1991. A cell-cycle-regulated trans-factor, DSCl, controls expression of DNA synthesis genes in yeast. Cold Spring Harbor Symp. Quant. Biol 56: 169-176.

Kilmartin, J.V., B. Wright, and C. Milstein. 1982. Rat monoclonal antitubulin antibodies derived by using a new nonsecreting rat cell line. J. Cell Biol. 93: 576-582.

Kim, H.B., B.K. Haarer, and J.R. Pringle. 1991. Cellular morphogenesis in the Saccharomyces cerevisiae cell cycle: Localization of the $C D C 3$ gene product and the timing of events at the budding site. I. Cell Biol. 112: 535-544.

Konopka, J.B. 1993. AFR 1 acts in conjunction with the $\alpha$-factor receptor to promote morphogenesis and adaptation. Mol. Cell. Biol. 13: 6876-6888.

Lee, K. and D. Levin. 1992. Dominant mutations in a gene encoding a putative protein kinase $(B C K 1)$ bypass the requirement for a Saccharomyces cerevisiae protein kinase $\mathrm{C}$ homolog. Mol. Cell. Biol. 12: 172-182.

Lee, K., K. Irie, Y. Gotoh, Y. Watanabe, H. Araki, E. Nishida, K. Matsumoto, and D. Levin. 1993. A yeast mitogen-activated protein kinase homolog ( $\mathrm{Mpklp}$ ) mediates signalling by protein kinase C. Mol. Cell. Biol. 13: 3067-3075.

Lew, D. and S. Reed. 1993. Morphogenesis in the yeast cell cycle: Regulation by $\mathrm{Cdc} 28$ and cyclins. J. Cell Biol. 120: $1305-1320$.

Lillie, S.H. and S.S. Brown. 1994. Immunofluorescence localization of the unconventional myosin, Myo2p, and the putative kinesin-related protein, Smylp, to the same regions of polarized growth in Saccharomyces cerevisiae. J. Cell Biol. 
SHR3: A novel component of the secretory pathway specifically required for localization of amino acid permeases in yeast. Cell 71: 463-478.

Madden, K. and M. Snyder. 1992. Specification of sites of polarized growth in Saccharomyces cerevisiae and the influence of external factors on site selection. Mol. Biol. Cell 3: 10251035.

Madden, K., C. Costigan, and M. Snyder. 1992. Cell polarity and morphogenesis in Saccharomyces cerevisiae. Trends Cell Biol. 2: 22-29.

Mazzoni, C., P. Zarzov, A. Rambourg, and C. Mann. 1993. $S L T 2$ (MPK1) MAP kinase homolog is involved in polarized cell growth in Saccharomyces cerevisiae. I. Cell Biol. 123: 1821-1823.

Moreno, S. and P. Nurse. 1990. Substrates for p34-cdc2: In vivo veritas? Cell 61: 549-551.

Neufeld, T.P. and G.M. Rubin. 1994. The Drosophila peanut gene is required for cytokinesis and encodes a protein similar to yeast putative bud neck filament proteins. Cell 77: 371379.

Nottenburg, C., W.M. Gallatin, and T.S. John. 1990. Lymphocyte HEV adhesion variants differ in the expression of multiple gene sequences. Gene 95: 279-284.

Orlean, P., M.J. Kuranda, and C.F. Albright. 1991. Analysis of glycoproteins from Saccharomyces cerevisiae. In Guide to yeast genetics and molecular biology (ed. C. Guthrie and G.R. Fink), pp. 682-697. Academic Press, San Diego, CA.

Page, B.D. and M. Snyder. 1992. CIK1: A developmentally regulated spindle pole body-associated protein important for microtubule functions in Saccharomyces cerevisiae. Genes \& Dev. 6: 1414-1429.

Park, H.O., J. Chant, and I. Herskowitz. 1993. BUD2 encodes a GTPase-activating protein for Bud1/Rsrl necessary for proper bud-site selection in yeast. Nature 365: 269-274.

Pringle, I., A.E.M. Adams, D.G. Drubin, and B.K. Haarer. 1991. Immunofluorescence methods for yeast, In Guide to yeast genetics and molecular biology (ed. C. Guthrie and G.R. Fink), pp. 565-601. Academic Press, San Diego, CA.

Pringle, J.R., E. Bi, H.A. Harkins, J.E. Zahner, C. DeVirgilio, J. Chant, K. Corrado, and H. Fares. 1995. Establishment of cell polarity in yeast. Cold Spring Harbor Symp. Quant. Biol. (in press).

Read, E.B., H.H. Okamura, and D.G. Drubin. 1992. Actin- and tubulin-dependent functions during Saccharomyces cerevisiae mating projection formation. Mol. Biol. Cell 3: 429444.

Rhyu, M.S. and J.A. Knoblich. 1995. Spindle orientation and asymmetric cell fate. Cell 82: 523-526.

Ridley, A. 1995. Rho-related proteins: Actin cytoskeleton and cell cycle. Curr. Opin. Genet. Dev. 5: 24-30.

Roemer, T., G. Paravicini, M. Payton, and H. Bussey. 1994. Characterization of the yeast (1-6)- $\beta$-glucan biosythetic components, Kre6p and Sknlp, and genetic interactions between the $\mathrm{PKCl}$ pathway and extracellular matrix assembly. J. Cell Biol. 127: 567-579.

Ron, D., M. Zannini, M. Lewis, R.B. Wickner, L.T. Hunt, G. Graziani, S.R. Tronick, S.A. Aaronson, and A. Eva. 1991. A region of proto-Dbl essential for its transforming activity shows sequence similarity to a yeast cell cycle gene, $C D C 24$, and the human breakpoint cluster gene, BCR. New Biol. 3: $372-379$.

Rothstein, R.J. 1983. One-step gene disruption in yeast. Methods Enzymol. 101: 202-211.

Sambrook, J., E.F. Fritsch, and T. Maniatis. 1989. Molecular Cloning: A laboratory manual. Cold Spring Harbor Labora- tory, Cold Spring Harbor, NY.

Sanders, S.L. and C.M. Field. 1994. Septins in common? Curr. Biol. 4: 907-910.

Sanger, F., S. Nicklen, and A.R. Coulson. 1977. DNA sequencing with chain-terminating inhibitors. Proc. Natl. Acad. Sci. 74: 5463-5467.

Schneider, B.L., W. Seufert, B. Steiner, Q.H. Yang, and A.B. Futcher. 1995. Use of PCR epitope tagging for protein taggins in Saccharomyces cerevisiae. Yeast 11: 1265-1274.

Schnepf, E. 1986. Cellular polarity. Annu. Rev. Plant Physiol. 37: 23-47.

Segall, J.E. 1993. Polarization of yeast cells in spatial gradients of $\alpha$-factor. Proc. Natl. Acad. Sci. 90: 8332-8336.

Shapiro, L. 1993. Protein localization and asymmetry in the bacterial cell. Cell 73: 841-855.

Shinjo, K., J.G. Koland, M.J. Hart, V. Narasimhan, D.I. Johnson, T. Evans, and R.A. Cerione. 1990. Molecular cloning of the gene for the human placental GTP-binding protein, Gp (G25K): Identification of this GTP-binding protein as the human homolog of the yeast cell division cycle protein, CDC42. Proc. Nat1. Acad. Sci. 87: 9853-9857.

Sloat, B.F., A. Adams, and J.R. Pringle. 1981. Roles of the CDC24 gene product in cellular morphogenesis during the Saccharomyces cerevisiae cell cycle. I. Cell Biol. 89: 395405.

Smith, D. and K. Johnson. 1988. Single-step purification of polypeptides expressed in Escherichia coli as fusion with glutathione S-transferase. Gene 67: 31-40.

Snyder, M. 1989. The SPA2 protein of yeast localizes to sites of cell growth. J. Cell Biol. 108: 1419-1429.

Snyder, M., S. Gehrung, and B.D. Page. 1991. Studies concerning the temporal and genetic control of cell polarity in Saccharomyces cerevisiae. I. Cell Biol. 114: 515-532.

Sun, G.H., Y. Ohya, and Y. Anraku. 1992. Yeast calmodulin localizes to sites of cell growth. Protoplasma 166: 110-113.

Torpey, L., P. Gibbs, J. Nelson, and C. Lawrence. 1994. Cloning and sequence of $R E V 7$, a gene whose function is required for DNA damage-induced mutagenesis in Saccharomyces cerevisiae. Yeast 10: 1503-1509.

Torres, L., H. Martin, M.I. Garcia-Saez, J. Arroyo, M. Molina, M. Sanchez, and C. Nombela. 1991. A protein kinase gene complements the lytic phenotype of Saccharomyces cerevisiae lyt2 mutants. Mol. Microbiol. 5: 2845-2854.

Trueheart, J. and G. Fink. 1989. The yeast cell fusion protein FUSl is O-glycosylated and spans the plasma membrane. Proc. Natl. Acad. Sci. 86: 9916-9920.

Walworth, N.C., B. Goud, H. Ruohola, and P. Novick. 1989. Fractionation of yeast organelles. Methods Cell Biol. 31: 335-354.

Welch, M.D., D.A. Holtzman, and D.G. Drubin. 1994. The yeast actin cytoskeleton. Curr. Opin. Cell Biol. 6: 110-119.

Wilson, I.A., H.L. Niman, R.A. Houghten, A.R. Cherenson, M.L. Connolly, and R.A. Lerner. 1984. The structure of an antigenic determinant in a protein. Cell 37: 767-778.

Ziman, M., D. Preuss, J. Mulholland, J.M. O'Brien, D. Botstein, and D.I. Johnson. 1993. Subcellular localization of Cdc42p, a Saccharomyces cerevisiae GTP-binding protein involved in the control of cell polarity. Mol. Biol. Cell 4: 1307-1316. 


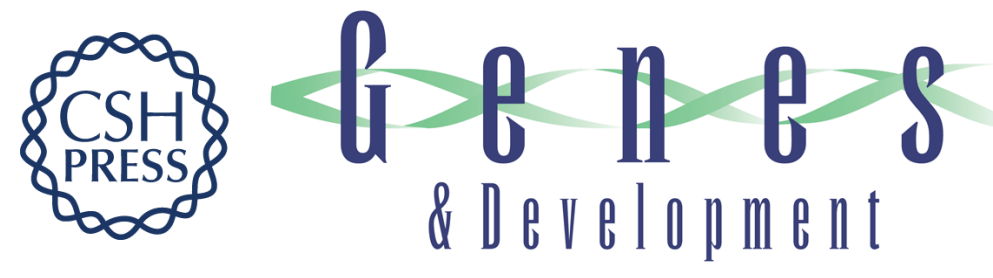

\section{Selection of axial growth sites in yeast requires AxI2p, a novel plasma membrane glycoprotein.}

T Roemer, K Madden, J Chang, et al.

Genes Dev. 1996, 10:

Access the most recent version at doi:10.1101/gad.10.7.777

References This article cites 89 articles, 44 of which can be accessed free at: http://genesdev.cshlp.org/content/10/7/777.full.html\#ref-list-1

License

Email Alerting Service

Receive free email alerts when new articles cite this article - sign up in the box at the top right corner of the article or click here.

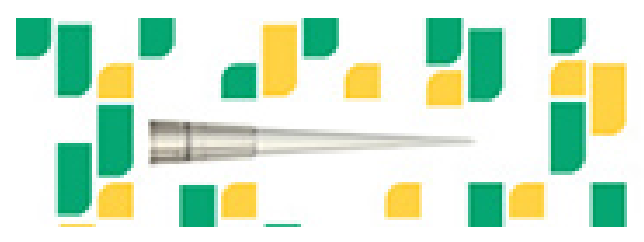

Focused on your science.

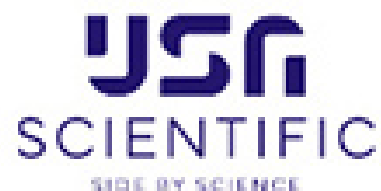

Copyright @ Cold Spring Harbor Laboratory Press 